medRxiv preprint doi: https://doi.org/10.1101/2020.06.17.20127407; this version posted June 22, 2020. The copyright holder for this preprint (which was not certified by peer review) is the author/funder, who has granted medRxiv a license to display the preprint in perpetuity.

All rights reserved. No reuse allowed without permission.

\title{
Perinatal Granulopoiesis and Risk of Pediatric Asthma
}

Authors: Benjamin A. Turturice BS ${ }^{1,2}$, Juliana Theorell BS ${ }^{2}$, Mary Dawn Koenig PhD RN $\mathrm{CNM}^{3}$, Lisa Tussing-Humphreys PhD MS RD ${ }^{4}$, Diane R. Gold MD MPH ${ }^{5,6}$, Augusto A. Litonjua, $\mathrm{MD}, \mathrm{MPH}^{7}$, Emily Oken MD MPH${ }^{8}$, Sheryl L. Rifas-Shiman $\mathrm{MPH}^{8}$, David L. Perkins MD $\mathrm{PhD}^{9,10, *}$, Patricia W. Finn MD ${ }^{1,2,10, *}$

\section{Affiliations:}

${ }^{1}$ Department of Microbiology and Immunology, University of Illinois at Chicago, Chicago, III ${ }^{2}$ Department of Medicine, Division of Pulmonary, Critical Care, Sleep, and Allergy, University of Illinois at Chicago, Chicago, III

${ }^{3}$ Department of Women, Children and Family Health Science, College of Nursing, University of Illinois at Chicago, Chicago, III

${ }^{4}$ Department of Medicine and Cancer Center, University of Illinois at Chicago, Chicago, III ${ }^{5}$ Channing Division of Network Medicine, Department of Medicine, Brigham and Women's Hospital, Harvard Medical School, Boston, Mass

${ }^{6}$ Department of Environmental Health, Harvard T.H. Chan School of Public Health, Boston, Mass

${ }^{7}$ Division of Pulmonary Medicine, Department of Pediatrics, University of Rochester, Rochester, NY

${ }^{8}$ Division of Chronic Disease Research Across the Life Course, Department of Population Medicine, Harvard Medical School and Harvard Pilgrim Health Care Institute, Boston, Mass ${ }^{9}$ Department of Medicine, Division of Nephrology, University of Illinois at Chicago, Chicago, III ${ }^{10}$ Department of Bioengineering, University of Illinois at Chicago, Chicago, III

\section{${ }^{*}$ Corresponding Authors:}

Patricia W. Finn email: pwfinn@uic.edu

David L. Perkins email: perkinsd@uic.edu

Author contributions: Conception and design: B.A.T., D.L.P., and P.W.F.; Data collection: B.A.T., M.K., L.T.H., D.R.G., A.A.L., E.O., D.L.P., and P.W.F; performed experiments: B.A.T., J.T.; analysis and interpretation: B.A.T., S.R.S., D.L.P., and P.W.F.; reagents and materials: M.K., L.T., D.L.P. and P.W.F.; manuscript writing: B.A.T., D.L.P., and P.W.F.; manuscript editing: M.D.K., L.T.H., D.R.G., A.A.L., and E.O.

Funding: This work was funded by the National Institutes of Health [grant nos. R01 Al 053878, F30 HL 136001, R01 HD 034568, and UH3 OD 023286], the Robert Wood Johnson Foundation [Nurse Faculty Scholars Program \#72117], the College of Nursing Dean's Award, and University of Illinois at Chicago Department of Medicine.

Competing Interests: The authors declare that they have no relevant conflicts of interest.

Word Count Manuscript (Introduction, Results, Discussion): 4005

Acknowledgments: Thanks to Kelly Liesse MD, Yishin Chang MS, and Wangfei Wang MS for their helpful comments regarding this manuscript. 
Abstract (Word Count 148):

Many perinatal characteristics are associated with risk for pediatric asthma. Identification

3 of biologic processes influenced by these characteristics could facilitate risk stratification or new

4 therapeutic targets. Using publicly available transcriptomic data from CBMCs, transcription of

5 genes involved in myeloid differentiation were inversely associated with pediatric asthma risk

6 stratification based on gestational age at birth, sex, birthweight, and maternal pre-pregnancy BMI.

7 This gene signature was validated in an independent cohort and was specifically associated with

8 genes localizing to neutrophil specific granules. Changes in these genes correlated with changes

9 in protein abundance in serum. CBMC serum levels of PGLYRP-1, a specific granule protein, and

10 sIL6Ra, a membrane protein, were tested for association with pulmonary outcomes. PGLYRP-1

11 concentration was inversely associated with mid-childhood current asthma and early-teen

$12 \mathrm{FEV}_{1} / \mathrm{FVCx} 100$. Thus, variation in neutrophil specific granule abundance at birth is associated

13 with individual risk for pediatric asthma and reduced pulmonary function in adolescence.

15 Key Words: 
medRxiv preprint doi: https://doi.org/10.1101/2020.06.17.20127407; this version posted June 22, 2020. The copyright holder for this preprint (which was not certified by peer review) is the author/funder, who has granted medRxiv a license to display the preprint in perpetuity.

All rights reserved. No reuse allowed without permission.

\section{Introduction}

Several risk factors for pediatric asthma can be ascertained in the perinatal period. These risk factors include maternal characteristics (e.g., maternal atopy, maternal BMI, race/ethnicity), demographics (e.g., newborn sex), and birth characteristics (e.g., birthweight, gestational age at birth, mode of delivery) (1). Meta-analyses have provided strong evidence for associations between the variables stated above and risk for pediatric asthma (2-5). Many of these risk factors co-occur (e.g., low birthweight and preterm birth) and it has yet to be discerned whether their imparted risk is mediated through similar biologic processes.

The maternal and fetal immune systems during pregnancy are biased towards Th2 responses and exhibit immune-tolerance to foreign antigens (6-8). Throughout the majority of gestation, fetal hematopoiesis generates mainly lymphoid and erythroid lineages. Towards term gestation, there is a shift towards generation of cells in the myeloid lineages (e.g. neutrophils, monocytes) (9). This phenomenon is evident clinically, as pre-term ( $<37$ weeks gestation) infants have higher lymphocyte to neutrophil ratios compared to those born term ( $\geq 37$ weeks gestation) (10). The myeloid compartment produces several cytokines (including IL1 $\beta$, IL-6, IL-18) and costimulatory molecules that shift CD4+ ${ }^{+}$-cells away from Th2 responses (11-13). With regards to outcomes, enhanced production of IFNy by leukocyte stimulation early in life is associated with reduced susceptibility to infections in the lower respiratory tract and recurrent wheezing; however, these findings have not been shown to extend to asthma diagnosis in childhood $(14,15)$.

Several meta-analyses assessing DNA methylation of peripheral blood leukocytes of children with and without asthma have identified differentially methylated regions proximal, or

47 within, genes specifically transcribed in eosinophils $(16,17)$. These findings are consistent with observations of enhanced Th2 responses in children with asthma (18). However, when assessing cord blood mononuclear cell (CBMC) samples, differential methylation did not extend to these and other classically Th2 associated loci (17). Additionally, randomized controlled trials using 
51 immunomodulatory products (e.g. Vitamin D, probiotics) in utero have failed to demonstrate

52 benefit in prevention of asthma $(19,20)$. Thus, a greater understanding of early-life immunologic

53 differences that are associated with predisposition to asthma may facilitate a more detailed risk

54 stratification, and ultimately, identification of potential therapeutic targets.

55 Our focus was to determine biologic processes-extending to both transcriptional and 56 serologic levels-associated with pediatric asthma risk that are detectable at birth. We

57 hypothesized that transcriptional changes in CBMCs associated with multiple epidemiologic risk

58 factors would be mediators of pediatric asthma risk. CBMCs have been previously studied with

59 regards to cytokine production, DNA methylation, and outcomes $(7,15,17,18,23)$, making them

60 ideal candidates for investigation. Here, we identify a novel association between epidemiologic

61 risk, neutrophil specific granules, and pediatric pulmonary outcomes.

62

63

64

65

66

67

68

69

70

71

72

73

74

75 
medRxiv preprint doi: https://doi.org/10.1101/2020.06.17.20127407; this version posted June 22, 2020. The copyright holder for this preprint (which was not certified by peer review) is the author/funder, who has granted medRxiv a license to display the preprint in perpetuity.

All rights reserved. No reuse allowed without permission.

\section{Results}

\section{Approach to Identify Immunologic Differences Associated with Risk for Pediatric Asthma}

We developed an analytic approach to identify genes whose expression in CBMCs are associated with newborns with higher or lower risk for asthma. We conducted a meta-analysis to increase power and generalizability (Figure 1A, B). In our approach, we queried NCBI's Gene Expression Omnibus for CBMC microarray datasets that included metadata regarding the demographics and birth characteristics that are risk factors for pediatric asthma. We identified 354 datasets from our original search, of which 17 datasets contained relevant metadata. Of the 17 studies the most common maternal and neonatal characteristics reported were newborn sex, gestational age at birth, birthweight and maternal pre-pregnancy BMI (PP BMI) at 69.96\%, $51.59 \%, 30.27 \%$, and $19.32 \%$ of samples, respectively. Metadata regarding maternal smoking and mode of delivery (i.e., vaginal vs. cesarean section) was reported for 3 datasets; however, 2 of these datasets originated from the same laboratory group and contributed the majority of samples reporting these factors. None of the identified datasets reported metadata about maternal atopy or child's ethnicity. Therefore, we chose to focus the analysis on gene expression associated with newborn sex, gestational age at birth, newborn weight and maternal PP BMI. 6 datasets were excluded due to homogenous metadata (e.g., all female). Datasets and the corresponding analysis are reported; a total of 605 unique transcriptomes were included (Table 1) $(21-31)$.

To validate the findings of the meta-analysis, we assessed three independent cohorts to confirm which genes are associated with asthma risk (Figure 1C). Further details regarding validation and outcomes follow in later result sections. In brief, the goal of validation was to assess gene expression in an independent cohort (UIH Cohort) where all subjects had complete metadata regarding newborn sex, gestational age, birthweight and PP BMI. We sought to further understand whether transcriptomic differences in CBMCs corresponded to differences at the 
medRxiv preprint doi: https://doi.org/10.1101/2020.06.17.20127407; this version posted June 22, 2020. The copyright holder for this preprint (which was not certified by peer review) is the author/funder, who has granted medRxiv a license to display the preprint in perpetuity.

All rights reserved. No reuse allowed without permission.

101 protein level (all three cohorts) or cell population level (Olin et al (32)). Finally, we assessed 2 102 identified proteins in another independent cohort (Project Viva Cohort) to test for association with 103 pediatric asthma and pulmonary function outcomes at 2 follow-up time points.

Meta-Analysis of CBMC Transcription Associated with Individual Perinatal Risk Factors

Univariate random effects models were generated to assess transcriptional changes in CBMCs with regards to newborn sex, gestational age, birthweight, and maternal PP BMI (Figure 2A). Differential expression (FDR < 1\%) was observed in 122, 34, 4, and 12 genes when comparing fetal sex, gestational age, birthweight, and maternal pre-pregnancy BMI, respectively (Supplemental Data 1-4). When evaluating sex and gestational age, several expected genes were identified to have large transcriptional changes. With regards to sex-associated transcriptional changes, although there was no $\mathrm{X}$ or $\mathrm{Y}$ chromosome-wide gene enrichment, several genes located on X (KDM5C, SMC1A, TXLNG, and KDM6A) and Y (KDM5D and EIF1AY)

114 chromosomes exhibited the largest effect sizes and most significant differences. In addition to expected sex-associated transcriptional changes, $H B E 1$, a hemoglobin subunit associated with fetal erythropoiesis, was significantly associated with pre-term gestational ages. To further

117 validate our gestational age findings, we compared our univariate analysis with previously 118 published results of differentially methylated regions associated with gestational age at birth 119 estimated by last menstrual period (33) (Figure S1). A significant association was observed 120 between differentially methylated genes and the effect size in our gestational age analysis, such 121 that genes whose methylation increased with gestational age as reported by Bohlin et al. (33) 122 showed on average decreased expression with gestational age in our meta-analysis. 
medRxiv preprint doi: https://doi.org/10.1101/2020.06.17.20127407; this version posted June 22, 2020. The copyright holder for this preprint (which was not certified by peer review) is the author/funder, who has granted medRxiv a license to display the preprint in perpetuity.

All rights reserved. No reuse allowed without permission.

To identify the biological processes that are enriched by genes with transcriptional changes associated with higher or lower risk of asthma, the z-scores from each univariate metaanalysis were averaged, such that negative z-statistics were associated with lower risk (female, older gestational ages, higher birthweights, and lower maternal PP BMI) and positive z-statistics were associated with increased risk. Thus, the pooled z-score indicates the average probability that a gene's expression is associated with either increased or decreased risk of asthma based on an individual's demographics and birth characteristics. The averaged z-statistic was used as a pre-ranked list for gene set enrichment analysis. GO terms were assessed for enrichment; 18 and $19 \mathrm{GO}$ terms were significantly enriched (FDR < 1\%) with regards to low and high risk profiles, respectively (Figure 2B). Genes associated with lower risk exhibited increased representation in GO terms involving innate immune signaling and defense, whereas high risk genes were enriched in pathways involving translation and RNA metabolic processes. tissues) can be influenced by the cellular composition. To determine if specific cell population enrichment was associated with the pooled z-score, the Human Protein Atlas (HPA, Monaco et al.) $(34,35)$ was utilized to assess the abundance of transcripts in peripheral blood leukocyte RNA

141 transcriptomes in relationship to the pooled z-score (Figure S2). We observed a generalized 142 increase in expression of low risk genes in myeloid cells and high risk genes in lymphoid cells. 143 This pattern of expression was most pronounced in neutrophils (Figure 2C). These results 144 suggest that lower risk individuals have increased populations of myeloid cells in their CBMCs.

147 first assessment, z-scores from each individual analysis correlated with the pooled z-score. The 148 highest correlations with the pooled z-score were the z-scores from the meta-analyses assessing 149 gestational age at birth, newborn sex, and birthweight. Individual dataset z-scores for each 
medRxiv preprint doi: https://doi.org/10.1101/2020.06.17.20127407; this version posted June 22, 2020. The copyright holder for this preprint (which was not certified by peer review) is the author/funder, who has granted medRxiv a license to display the preprint in perpetuity.

All rights reserved. No reuse allowed without permission.

dataset demonstrated a similar trend. In the second assessment, z-scores from each individual analysis were correlated with the combination of all other z-scores. Again, the pooled z-score had

152 the highest average correlation followed by the meta-analyses. Together, this demonstrates that

153 the pooled z-score does, indeed, amalgamate information across all of the analyses, with the 154 most influence arising from gestational age at birth, newborn sex, and birthweight.

Specific Granule Gene Expression Association with Multiple Pediatric Asthma Risk Factors

To confirm gene expression changes associated with asthma risk stratification, pooled zscores from the meta-analysis were compared with the UIH cohort, a cohort of individuals in which newborn sex, maternal PP BMI, gestational age at birth, and birthweight were known (Supplemental Data 5). UIH cohort z-scores were calculated from mRNAseq of CBMCs, where gene expression was modeled as a function of number of risk factors (Supplemental Data 6). We developed a method to validate the congruence between the UIH cohort and the pooled metaanalysis, which we termed the replication score (RS). This RS is the product of the pooled z-score from the meta-analysis and the UIH z-score (see methods). We assessed the relationship between RS cutoff, p-values, and number of genes (Figure S2). Genes with a replication score greater than 3 were identified as being sufficiently congruent. 51 genes, $0.4 \%$ of all genes tested had a RS greater than 3 (Figure 3A). These identified genes corresponded well with the results of pooled z-score for gestational age at birth, newborn sex and birthweight, but showed limited correlation to maternal PP BMI. They had median p-values of $0.02,0.01,0.11$, and 0.58 in the

170 gestational age at birth, newborn sex, birthweight, and maternal PP BMI meta-analyses, and 171 median p-value of 0.02 in the UIH cohort.

172 Replicating genes were enriched for processes involved in vesicle biology (Figure S3). 173 Specifically, replicating genes associated with low risk were enriched for genes that are 174 components of granulocyte specific granules (MS4A3, CEACAM8, OLR1, CAMP, LTF, CHI3L1, 
medRxiv preprint doi: https://doi.org/10.1101/2020.06.17.20127407; this version posted June 22, 2020. The copyright holder for this preprint (which was not certified by peer review) is the author/funder, who has granted medRxiv a license to display the preprint in perpetuity.

All rights reserved. No reuse allowed without permission.

SLPI, PGLYRP1). With regards to genes associated with higher risk, genes involved in vesicle sorting/production (VPS28, VTI1B, FIS1) as well as several genes involved in vesicle membrane biology (AGPAT3, ELOVL6, TM7SF2) were identified.

To test whether replicating genes were associated with the number of risk factors, these 51 genes were assessed using principal component analysis. Using the first Eigenvector (explaining $41.3 \%$ of variance in replicating genes), a significant association $(\mathrm{R}[95 \% \mathrm{Cl}]=-0.51[-$ 0.73, -0.18], p-value < 0.01) was observed between UIH cohort Eigenvalues and number of epidemiologic risk factors (Figure 3B). Positive eigenvalues represent increased expression of low risk genes and negative eigenvalues represent increased expression of high risk genes. Although the associations with individual risk factors were in the expected directions, they were not significant (Figure 3C), suggesting that the additive effect is greater than the individual.

\section{Cellular and Protein Abundance in Relation to Pediatric Asthma Risk Factors}

To further determine if these changes are due to differences in cellular populations, we analyzed mass cytometry data published by Olin et al. for abundance of 21 different cell types in relationship to number of epidemiologic risk factors for pediatric asthma (32). Cord blood neutrophil abundance was inversely associated $(R[95 \% \mathrm{Cl}]=-0.57[-0.73,-0.34]$, Bonferroni $p-$ adj $<0.001$ ) with the number of risk factors (Figure 4A). Other myeloid cell types, CD14+ monocytes and myeloid-derived dendritic cells, also had negative correlations but were weaker and not significant after multiple testing correction (data not shown).

Extending these findings from gene expression to protein abundance, reported umbilical cord plasma protein abundance data was correlated with number of risk factors in a secondary analysis (32). Serum proteins from genes that replicated with low risk had on average negative correlations with number of risk factors (Figure 4B). No proteins from the high risk genes were tested in plasma, due to their intracellular localization. Notably, proteins (CEACAM8, PGLYRP-1, 
medRxiv preprint doi: https://doi.org/10.1101/2020.06.17.20127407; this version posted June 22, 2020. The copyright holder for this preprint (which was not certified by peer review) is the author/funder, who has granted medRxiv a license to display the preprint in perpetuity.

All rights reserved. No reuse allowed without permission.

CHIT1, sIL6Ra, MMP-9, and OSM) predicted to be enriched in neutrophils by the HPA (34) had strong correlations with both neutrophil abundance and number of risk factors (Figure 4B-C).

We hypothesized that the serum concentration of proteins identified as low risk in our transcriptomic analysis would correlate with mRNA abundance in CBMCs, whereas those not associated with risk would not correlate with mRNA in CBMCs. To test this hypothesis, we used the UIH cohort to correlate mRNA abundance with serum protein concentration of PGLYRP-1 (low risk) and sIL6Ra (no risk). We observed a significant $(\mathrm{R}[95 \% \mathrm{Cl}]=0.39[0.03,0.66], \mathrm{p}<0.05)$ association between PGLYRP-1 protein concentration and mRNA (Figure 4D). Consistent with transcriptomic results, PGLYRP-1 cord blood serum concentration was inversely associated with number of risk factors $(\mathrm{R}[95 \% \mathrm{Cl}]=-0.51[-0.74,-0.17], \mathrm{p}<0.01)$. sIL6R $\alpha$ was neither associated with its mRNA in CBMCs $(R[95 \% \mathrm{Cl}]=0.37[-0.22,0.77], p=0.21)$ nor the number of risk factors $(\mathrm{R}[95 \% \mathrm{Cl}]=0.20[-0.39,0.67], \mathrm{p}=0.50)$.

\section{Demographic Associations with Serum Neutrophil Proteins in UIH and Project Viva Cohorts}

We tested the association between PGLYRP-1 and sIL6Ra, individual risk factors and demographics in the UIH and Project Viva cohorts. Cord blood serum was available in a subset of individuals $(\mathrm{n}=358)$ from Project Viva (Supplemental Data 7). There was no significant difference ( $p>0.05$, Wilcoxon rank sum test) in PGLYRP-1 or sIL6Ra between UIH and Project Viva cohorts (Figure S4). Consistent with our previous observations, PGLYRP-1 and sIL6R $\alpha$ were positively correlated in both UIH $(R[95 \% \mathrm{Cl}]=0.21[-0.16,0.54])$ and Project Viva $(\mathrm{R}[95 \% \mathrm{Cl}]$ $=0.19[0.09,0.29])$ cohorts. Although there were no significant associations between PGLYRP-1 or sIL6Ra with any single demographic in all three data sets, there was a small positive association between PGLYRP-1 and gestational age at birth (Table 2). Collectively, these results suggest that increased abundance of mRNA from genes localizing to neutrophil specific granules 
medRxiv preprint doi: https://doi.org/10.1101/2020.06.17.20127407; this version posted June 22, 2020. The copyright holder for this preprint (which was not certified by peer review) is the author/funder, who has granted medRxiv a license to display the preprint in perpetuity.

All rights reserved. No reuse allowed without permission.

are associated with the number of risk factors for pediatric asthma. These changes in mRNA are reflected in the abundance of these specific granule proteins in serum and plasma.

\section{Serum Neutrophil Proteins Associations with Pediatric Pulmonary Outcomes}

In context of our previous results, we hypothesize that specific granule protein abundance in serum is associated with risk of pediatric asthma and this process is independent of neutrophil abundance. To evaluate this hypothesis, we measured PGLYRP-1 (present in neutrophil specific granule and correlates with its mRNA in CBMCs) and sIL6Ra (derived from neutrophils but not present in specific granules and does not correlate with its mRNA in CBMCs) in umbilical cord blood serum. At two follow up time-points, asthma outcomes and expiratory flow volumes were modeled as a function of PGLYRP-1 and sIL6Ra in a subset of individuals in Project Viva (Figure S5). The demographics of the subset of individuals from Project Viva from which umbilical cord serum was available had a similar demographic profile as the full cohort. One notable difference was a sizeable decreased response rate for asthma outcomes at the early-teenage follow-up compared to the full cohort (32\% subset vs. $47 \%$ full cohort).

PGLYRP-1 and sIL6Ra were modeled as predictors for current asthma at mid-childhood (median age $~ 7.7$ years old) and early-teen (median age $\sim 12.8$ years old) follow-ups (Table 3). Four regression models were used to estimate the association between asthma outcomes: univariate, adjustment for child's birth characteristics and demographics, adjustment for mother's demographics, and adjustment for birth characteristics and all demographics (reported in manuscript). The abundance of PGLYRP-1 was significantly associated with current asthma at mid-childhood (adjusted OR [95\% Cl]: $0.50[0.31,0.77]$ per 1 SD increase, p-value $=0.003$ ) (Figure 5A). There were no significant associations between current asthma and PGLYRP-1 at the early-teen follow-up, however the confidence interval at this time-point was much wider, likely 
medRxiv preprint doi: https://doi.org/10.1101/2020.06.17.20127407; this version posted June 22, 2020. The copyright holder for this preprint (which was not certified by peer review) is the author/funder, who has granted medRxiv a license to display the preprint in perpetuity.

All rights reserved. No reuse allowed without permission.

secondary to the smaller sample size. There were no significant association between sIL6Ra with any asthma outcome at either time-point.

We also performed analyses to estimate the relationship of cord blood PGLYRP-1 and slL6R $\alpha$ with $\mathrm{FEV}_{1} / \mathrm{FVCx} 100$ ratio and bronchodilator response (BDR) at mid-childhood and earlyteen follow-up time points (Table 4). There was no significant association between sIL6Ra and FEV $_{1} /$ FVCx100 ratio at either time-point. PGLYRP-1 and slL6Ra were not associated with BDR at either time-point. However, there was trend towards an association between PGLYRP-1 concentration and $\mathrm{FEV}_{1} / \mathrm{FVCx} 100$ ratio at mid-childhood (adjusted $\beta[95 \% \mathrm{Cl}]: 1.18[-0.18,2.56]$ per 1SD increase, $p$-value $=0.09$ ) and significant association at the early-teen follow up (adjusted $\beta[95 \% \mathrm{Cl}]: 1.15[0.20,2.10]$ per 1SD increase, $\mathrm{p}$-value $=0.02)$ (Figure 5B).

To further our understanding of the relationship between PGLYRP-1 and outcomes, we performed two secondary analyses of models adjusted for all demographics and birth characteristics. First, we assessed the total variance explained by the regression model adjusting for both birth characteristics and demographics, and the variance explained by each of the individual predictors in the model. Assessing current asthma risk at mid-childhood, the regression model explained approximately $18 \%$ of the variance, and PGLYRP-1 was the most important predictor (Figure S6). Assessing current FEV1/FVCx100 at early-teen time-point, the model explained approximately $26 \%$ of variance, and PGLYRP-1 was the second most important predictor (Figure S6). Second, to identify covariates that modify the effect of PGLYRP-1, we performed subset analyses (Figure S7). Small for gestational age and children identified by their mothers as "Other" race/ethnicity displayed significantly different associations between PGLYRP1 and mid-childhood asthma. Small for gestational age and children with obese mothers displayed significantly different associations between PGLYRP-1 and FEV1/FVC.

These findings implicate a role for PGLYRP-1 and other specific granule proteins as predictors of pediatric asthma risk and pulmonary function. This is in contrast to sIL6Ra, which is 
medRxiv preprint doi: https://doi.org/10.1101/2020.06.17.20127407; this version posted June 22, 2020. The copyright holder for this preprint (which was not certified by peer review) is the author/funder, who has granted medRxiv a license to display the preprint in perpetuity. All rights reserved. No reuse allowed without permission.

273 not localized to specific granules, its protein abundance is not regulated by transcription, and is

274 not associated with any pulmonary outcomes.

275

276

277

278

279

280

281

282

283

284

285

286

287

288

289

290

291

292

293

294

295

296

297 
medRxiv preprint doi: https://doi.org/10.1101/2020.06.17.20127407; this version posted June 22, 2020. The copyright holder for this preprint (which was not certified by peer review) is the author/funder, who has granted medRxiv a license to display the preprint in perpetuity.

All rights reserved. No reuse allowed without permission.

\section{Discussion}

Our study has identified a novel association between epidemiologic risk, neutrophil specific granules, and pediatric pulmonary outcomes. By pooling the meta-analysis results, we established an association between multiple risk factors and the expression of genes involved in innate immunity and nucleic acid metabolism. We hypothesized that this gene signature represents increased myelopoiesis in utero and correlates with perinatal risk for pediatric asthma. During the process of myeloid cell differentiation, production of proteins responsible for defense against microbes and pro-inflammatory signaling (e.g., IL-1ß) are amplified, while translational activity and nucleolar size wane $(36,37)$. In our analysis, lower risk genes had higher expression in myeloid cells, most notably neutrophils. The low risk genes were enriched for those that are implicated in defense responses towards bacteria and fungi. Additionally, this gene signature was strongly correlated with gestational age at birth, newborn sex, and birthweight (weaker association with maternal PP BMI). Our findings parallel previous literature, which has demonstrated that preterm birth, male sex, and low birthweight are associated reduced abundance of neutrophils and monocytes (10).

Our replication of the pooled meta-analysis with the UIH cohort pointed towards genes

314 located and involved in the biology of neutrophil specific (secondary) granules. In particular, lower risk individuals had higher expression of genes whose protein products are luminal (PGLRYP1, LTF, PTX3, CHI3L1, CAMP, SLPI) and membrane (CEACAM8, MS4A3, OLR1) components of 317 specific granules (38). It is known that gestational age at birth, sex, mode of delivery, and 318 birthweight may influence not only the abundance of neutrophils, but also their functionality (e.g. 319 phagocytosis, cytokine production, respiratory burst) (39). We demonstrate that the additive effect 320 of multiple risk factors is associated reduction of transcription and protein products of specific 321 granules in umbilical cord blood serum. Notably, our reanalysis of mass cytometry and proteomic 322 data demonstrated a correlation between PGLYRP-1 in serum and neutrophil abundance (32). 
medRxiv preprint doi: https://doi.org/10.1101/2020.06.17.20127407; this version posted June 22, 2020. The copyright holder for this preprint (which was not certified by peer review) is the author/funder, who has granted medRxiv a license to display the preprint in perpetuity.

All rights reserved. No reuse allowed without permission.

Previous literature has shown that deficiency of SLPI leads to impairment of neutrophil development and abundance (40). Further, individuals with specific granule deficiency syndrome have abnormal neutrophil morphology, increased susceptibility to infections, and increased risk of acute myeloid leukemia (41). Thus, it is likely that neutrophil differentiation and survival is partially dependent on secondary granule generation.

To further investigate how these findings are related to pediatric asthma, we chose to compare PGLYRP-1, sIL6Ra, and their associations with asthma and lung function outcomes. PGLYRP-1 and sIL6Ra were chosen because both were correlated with neutrophil abundance, yet they are derived from different processes. Variation in abundance of PGLYRP-1 in serum is due to changes in neutrophil degranulation and transcription of $P G L Y R P 1$, whereas sIL6Ra is derived from receptor shedding and differential splicing of its mRNAs $(42,43)$. Thus, if perinatal neutrophil abundance is associated with pediatric asthma both PGLYRP-1 and sIL6Ra should demonstrate associations with these outcomes. In contrast, we observed a significant relationship between mid-childhood asthma and PGLYRP-1 not sIL6Ra, indicating that serum abundance of specific granule contents is associated with risk and not the abundance of cord blood neutrophils.

Whether PGLYRP-1 has a causal role in asthma pathogenesis or is merely a biomarker for risk remains to be determined. PGLYRP-1 has antimicrobial function, although the concentration we observed in cord blood is below those reported for in vitro studies (44-46). PGLYRP-1 functions synergistically in vitro with other antimicrobials (e.g. lysozyme), so potential benefit as an antimicrobial cannot be ruled out $(45,46)$. Interestingly, mammalian PGLYRP-1 does not hydrolyze peptidoglycan and its orthologues appear divergent from ancestral PGLYRPS which contain enzymatic activity, thus it may have roles other than that of an antimicrobial (47). It is also possible that other individual specific granule proteins or their cumulative effects are associated with pediatric asthma. Further studies will be required to determine a mechanistic role for either PGLYRP-1 or other specific granule proteins. 
medRxiv preprint doi: https://doi.org/10.1101/2020.06.17.20127407; this version posted June 22, 2020. The copyright holder for this preprint (which was not certified by peer review) is the author/funder, who has granted medRxiv a license to display the preprint in perpetuity.

All rights reserved. No reuse allowed without permission.

There are several murine studies linking PGLYRP-1 to increased airway resistance and perturbed immunity in response to house dust mite $(48,49)$. These murine studies have utilized adult mice deficient in PGLYRP-1 via germ-line deletion. One study has demonstrated that bone marrow reconstitution with WT bone marrow prior allergen sensitization abrogates this effect (49), suggesting PGLYRP-1 presence in adult mice at the time of sensitization is responsible for increased airway resistance and perturbed immunity. This is not surprising as PGLYRP-1 is reported to be a pro-inflammatory TREM-1 ligand and thus may propagate inflammation (43).

355 Furthering this point, there are reported associations between increased serum PGLYRP-1 and systemic inflammatory conditions in adulthood (e.g. rheumatoid arthritis, cardiovascular disease) $(50,51)$. Notably, PGLYRP-1 and many of the other specific granule proteins are dramatically reduced in serum concentration one week postnatal (32). Murine studies using conditional knockouts at birth would better assess how the natural variation of PGLYRP-1 effects the susceptibility to pediatric asthma.

Although our findings contribute to our understanding of the risk for pediatric asthma, there are limitations. At the early-teen follow up, we did not observe a significant association with current asthma. It is important to note that there was still an association between PGLYRP-1 and FEV1/FVC at this time-point. These observations could be due two possibilities. First, at earlyteen follow-up, there was only $9 \%$ prevalence of current asthma in the Project Viva subset, whereas the full cohort had a $15 \%$ prevalence. This difference is likely due to higher non-response rates in the asthmatic sub-group as 24 of the $35(68 \%)$ had missing responses, whereas only 46 of $171(27 \%)$ of non-asthmatics had missing responses. This lead to a reduction in power at the 369 early-teen follow-up time point, potentially leading to a false negative result. Second, PGLYRP-1 370 might be inversely associated with FEV1/FVC in adolescence secondary to early-life pulmonary 371 dysfunction (e.g. mid-childhood asthma). Reduced expiratory pulmonary function later in 372 adolescences and even into adulthood is associated with individuals who were diagnosed with 
373 asthma in childhood (52-55). We view these possibilities as equally probable as current pediatric

374 asthma can also impair FEV1/FVC (56). Further investigation will be need to elucidate the role of

375 PGLYRP-1 in adolescent asthma.

376 In conclusion, we have identified a neutrophil development gene signature that is

377 associated with perinatal asthma risk. A soluble specific granule protein, PGLYRP-1, was strongly

378 associated with odds of asthma in childhood and pulmonary function in childhood and

379 adolescence. This suggests that perinatal granulopoiesis has a significant impact on the

380 development of pediatric asthma and lung function.

381

382

383

384

385

386

387

388

389

390

391

392

393

394

395

396

397 
medRxiv preprint doi: https://doi.org/10.1101/2020.06.17.20127407; this version posted June 22, 2020. The copyright holder for this preprint (which was not certified by peer review) is the author/funder, who has granted medRxiv a license to display the preprint in perpetuity.

\section{Methods}

\section{Human Subjects Project Viva Cohort}

The current study was approved by the University of Illinois at Chicago IRB (\#2016-0326) and the IRB of Harvard Pilgrim Health Care. Volunteers were recruited from women attending 402 their first prenatal visit at one of 8 practices of Atrius Harvard Vanguard Medical Associates. The 403 exclusion criteria were multiple gestation, inability to answer questions in English, gestational age $404 \geq 22$ weeks at recruitment, and plans to move away before delivery. The cohort profile was 405 previously described by Oken and colleagues (57). professional ever told you that your child has asthma?" and "yes" to either "In the past 12 months, 408 has child taken or been prescribed Albuterol, Cromolyn, Nedocromil, Montelukast, inhaled corticosteroids, or Prednisone" or "In the past 12 months, has your child ever had wheezing (or whistling in the chest)?". We used as a comparison group those with no asthma diagnosis and no

411 asthma medication use or wheezing in the past 12 months. We used the same definition for 412 current asthma in early adolescence, except the time reference for asthma medication was "in 413 the past month". Ever asthma was defined as a "yes" response to "Has a health professional ever 414 told you that your child has asthma?" within either the mid-childhood or early-teen follow up 415 periods. We used as a comparison group those with no asthma diagnosis. Individuals with missing 416 data were not used in regression models assessing current or ever asthma outcomes. Individuals 417 with missing data are reported in demographics tables and displayed in figure as "Missing Data". Methods for obtaining spirometric measurements and bronchodilator response have been 419 described previously (56). In brief, spirometry was performed with the EasyOne Spirometer (NDD 420 Medical Technologies, Andover, Mass). Post-bronchodilator spirometric measures were obtained 421 at least 15 minutes after administration of 2 puffs (90 $\mu \mathrm{g}$ per puff) of albuterol. Spirometric 422 performance was required to meet American Thoracic Society criteria for acceptability and 
medRxiv preprint doi: https://doi.org/10.1101/2020.06.17.20127407; this version posted June 22, 2020. The copyright holder for this preprint (which was not certified by peer review) is the author/funder, who has granted medRxiv a license to display the preprint in perpetuity.

All rights reserved. No reuse allowed without permission.

423 reproducibility, with each subject producing at least 3 acceptable spirograms, 2 of which must

424 have been reproducible $(57,58)$.

425

\section{Human Subjects University of Illinois Hospital Cohort}

The current study was approved by the University of Illinois at Chicago IRB (\#2015-0353).

Women seeking prenatal care at the University of Illinois at Chicago (UIC) Center for Women's

429 Health were recruited as volunteers in their third trimester (29-33 weeks of gestation) between

4302014 and 2017. The cohort profile has been previously described by Koenig and colleagues (59).

431 Inclusion criteria as follows: singleton pregnancy; naturally conceived pregnancy; $17-45$ y of age;

432 pre-pregnancy $\mathrm{BMI} \geq 18.5 ;<34$ weeks of gestation; sufficient fluency in English to provide consent

433 and complete the study; and ability to independently provide consent. Exclusion criteria as follows:

434 live birth or another pregnancy (including ectopic and molar pregnancies) in the previous 12

435 months; preeclampsia; gestational diabetes mellitus or previously diagnosed type 1 or type 2

436 diabetes; autoimmune disorder; current or previous premature rupture of membranes or

437 chorioamnionitis; previous spontaneous premature birth; current bacterial or viral infection;

438 current steroid or anti-inflammatory treatment; history of bariatric surgery; malabsorptive condition

439 (e.g., celiac disease); current hyperemesis; hematologic disorder (e.g., sickle cell anemia or trait,

440 hemochromatosis); current tobacco use; alcohol consumption or illicit drug use; and current use

441 of medications that decrease nutrient absorption (e.g., proton pump inhibitors). All women

442 provided written informed consent.

$444 \quad$ Umbilical Cord Blood Specimens

$445 \quad$ For Project Viva, procedures for obtaining umbilical cord blood serum have been describe 446 previously (60). For the UIH cohort, umbilical cord blood was obtained by venipuncture shortly 447 after time of delivery. Blood (approximately $5 \mathrm{~mL}$ per tube) was drawn into Red Top Serum Plus 
medRxiv preprint doi: https://doi.org/10.1101/2020.06.17.20127407; this version posted June 22, 2020. The copyright holder for this preprint (which was not certified by peer review) is the author/funder, who has granted medRxiv a license to display the preprint in perpetuity.

All rights reserved. No reuse allowed without permission.

and Green Top Sodium Heparin 95 USP Units Blood Collection Tubes (BD Vacutainer). Red Tops were allowed to stand upright at room temperature for 30 min prior centrifugation at $1500 \times \mathrm{g}$ for 10 minutes at room temperature. Supernatants (serum) were collected, aliquoted, and stored at 80C until further processing. Heparinized blood obtained in Green Tops was diluted 1:1 in 1x Phosphate Buffered Saline, pH 7.4 (PBS) and overlaid onto Ficoll-Paque ${ }^{\mathrm{TM}}$ Plus (GE Healthcare) density gradients. Density gradients were centrifuged at $400 \mathrm{x} \mathrm{g}$ for 30 minutes at room temperature without brake. Upper phase (diluted plasma) was drawn off, aliquoted, and stored at -80C. Buffy coats (CBMCs) were drawn off, washed twice with $10 \mathrm{~mL}$ of $1 \times$ PBS, aliquoted and stored in $500 \mathrm{~mL}$ of RNAlater (Qiagen). Viability and number of cells isolated was determined by diluting cellular suspensions 1:1 with Trypan Blue Solution 0.4\% (w/v) in PBS (Corning) and counting live/dead cells $>7 \mu \mathrm{M}$ using a TC20 ${ }^{\mathrm{TM}}$ Automated Cell Counter (Biorad). The viability of isolated cells was $>90 \%$ for all samples. Time from delivery to storage was recorded for every sample.

\section{RNA Extraction and Sequencing}

Total RNA was extracted from CBMCs using RNeasy kits (QIAGEN) following manufacturers protocol except for switching $70 \%$ ethanol for $100 \%$ ethanol. The quality and quantity of all the extracted RNA was analyzed with a RNA 6000 Nano Kit on the 2100 Bioanalyzer Instrument (Agilent) and ssRNA High Sensitivity Kit and Qubit (Invitrogen). RIN for all samples was > 8. RNA was constructed into barcoded libraries using the TruSeq Stranded mRNA Library Prep Kit (Illumina). The pooled libraries were sequenced for a paired-end 151 read length. The DNA libraries were sequenced on HiSeq X Ten platform using HiSeq Reagent v2.5 kit (Illumina), following manufacturer's protocol.

\section{Enzyme-linked Immunosorbent Assays (ELISA)}


medRxiv preprint doi: https://doi.org/10.1101/2020.06.17.20127407; this version posted June 22, 2020. The copyright holder for this preprint (which was not certified by peer review) is the author/funder, who has granted medRxiv a license to display the preprint in perpetuity.

All rights reserved. No reuse allowed without permission.

474 and Human IL-6 R alpha DuoSet Elisa (R\&D Systems). Serum was diluted with 1\% BSA in PBS

475 (pH 7.2-7.4, 0.2 micron filtered) at 1:100 for PGLYRP-1 and 1:300 for sIL6Ra. ELISAs were

476 performed according to manufacturer's protocol. All samples were run in duplicate. Optical

477 Densities were assessed at 450 and 540 using a Spectra Max M5 (Molecular Devices). The intra-

478 and inter- plater CVs for PGLYRP-1 were $2.4 \%$ and $11.0 \%$. The intra- and inter- plater CVs for 479 sIL6Ra were $3.8 \%$ and $18.9 \%$.

Statistical Analysis

482 All statistical analyses were performed in $R$ (https://www.r-project.org/) unless otherwise specified.

Meta-Analysis

To identify datasets studies used in the meta-analysis, NCBl's Gene Expression Omnibus

487 (https://www.ncbi.nlm.nih.gov/geo) was searched using the search "(cord blood) AND "Homo metadata reported. 17 studies met inclusion criteria of reporting metadata regarding at least one

491 perinatal risk factor (e.g. gestational age at birth, newborn sex, birthweight, maternal pre492 pregnancy BMI, smoke exposure, mode of delivery) and expression data from either whole cord 493 blood or cord blood mononuclear cells derived from human subjects. Expression, feature, and 494 subject demographic data was extracted using geoquery (61). If expression data was non495 normalized, it was quantile normalized and log2 transformed. Six studies were excluded due to 496 no variability in demographic data (i.e. only males) or low data quality, leaving 605 unique cord 497 blood gene expression samples. To assess associations between gene expression and perinatal 
medRxiv preprint doi: https://doi.org/10.1101/2020.06.17.20127407; this version posted June 22, 2020. The copyright holder for this preprint (which was not certified by peer review) is the author/funder, who has granted medRxiv a license to display the preprint in perpetuity.

All rights reserved. No reuse allowed without permission.

risk factors, univariate, inverse variance weighted, random effects models were constructed for genes using the GeneMeta package (62). Newborn sex (Male vs. Female), maternal prepregnancy $\mathrm{BMI}$ (continuous: $0=\mathrm{BMl}<18.5,1=18.5 \leq \mathrm{BMl}<25,2=25 \leq \mathrm{BMl}<30,3=30 \leq \mathrm{BMI}$ ), gestational age at birth in weeks (continuous), and birthweight in grams (continuous) were assessed as perinatal risk factors. Significant genes were defined as Benjamini-Hochberg correct $p$-value $<0.01$. The $z$-score for each gene was averaged across each univariate test (Equation

1) and termed pooled z-score. It was used to assess how likely a gene is effected by multiple risk factors. If a gene was not assessed in one of the univariate analyses while assessed in others, the missing data was inferred as a z-score of zero. To determine cell enrichment, genes expression in each cell as defined by HPA $(34,35)$ were modeled as a function of the pooled zscore using general additive model with cubic splines function. To determine biological processes enriched in the low vs. high risk individuals, the pooled z-score was used a pre-ranked list for gene set enrichment analysis for GO biologic processes using GSEA (63). Significantly enriched GO terms were defined as Benjamini-Hochberg correct $p$-value $<0.01$. Spearman's correlations between pooled z-score, univariate z-scores, and individual data set z-scores were determined in $R$.

Equation 1: $Z_{\text {pooled }}=\frac{\left(\left(Z_{\text {Male }}+Z_{P P B M I}\right)-\left(Z_{G A}+Z_{B W}\right)\right)}{4}$

The sequences were quality controlled by filtering out all low-quality reads (<25 on Phred quality score) and short reads (<50 bp). Transcripts were annotated using salmon v0.12.0 and

519 Ensembl Homo sapiens Genome Assembly GRCh38.12 (64). Transcript counts were aggregated 520 in gene level counts using the tximport package in $\mathrm{R}$ (65). Genes with median counts across 521 samples < 10 were filtered out, leaving 14,055 genes remaining whose expression normalized using median sum scaling. Normalized gene expression was modeled as function of the number 
medRxiv preprint doi: https://doi.org/10.1101/2020.06.17.20127407; this version posted June 22, 2020. The copyright holder for this preprint (which was not certified by peer review) is the author/funder, who has granted medRxiv a license to display the preprint in perpetuity.

All rights reserved. No reuse allowed without permission.

523 of perinatal risk factors (gestational age $<37$ weeks, birthweight $<3000 \mathrm{~g}$, PP BMl $>30$, Male)

524 using DESeq2 (66). Genes were ranked for replication by their product of their pooled z-score

525 and RNAseq z-score, termed replication score (RS) (Equation 2). A cutoff of RS > 3 was used to

526 determine candidate genes associated with pediatric asthma risk. Candidate gene biologic

527 process and cellular component enrichment was performed using STRING with default settings

528 (67). Data from RNAseq is available on NCBI SRA database ID PRJNA577955.

Equation 2: $R S=Z_{\text {pooled }} \times Z_{R N A s e q}$

530

Secondary Statistical Analysis of Mass Cytometry and ProSeek Data (Olin et al)

Methods for data acquisition for cell population percentages and protein abundances

percentages were transformed using centered-log ratios. Cell populations and Protein

abundances, and number of risk factors for each individual (gestational age $<37$ weeks, male,

birthweight $<3000 \mathrm{~g}$, birth via c-section) were correlated (Pearson's method). For cell population correlations with number of risk factors, significance was defined as Bonferroni corrected p-value

$<0.05$. Proteins determined to neutrophil associated was determined by those expressed in CBMC (UIH cohort) and enriched in neutrophils HPA (34).

Asthma and Pulmonary Outcomes Statistical Analysis (Project Viva)

543 logistic regression. Continuous outcomes were modeled using linear regression. Four regression

544 models were used for each outcome: univariate/unadjusted, model1 adjusted for child's 545 demographics (gestational age at birth in weeks, birthweight adjusted for gestational age and sex, 546 mode of delivery, sex, and race/ethnicity), model 2 adjusted for maternal demographics (PP BMI, 547 race/ethnicity, level of education, atopy, antibiotic use during pregnancy, and smoking during 
548 pregnancy, 6 months, or 1 year), model 3 adjusted for both mother and child's demographics

549 (excluding maternal race/ethnicity). For regression models, PGLYRP-1 and sIL6Ra was log10

550 transformed and standardized to internal z-score. Subset analysis was performed by splitting the

551 full data set by categorical variables and modeling outcomes as function of PGLYRP-1 in each

552 subset using the univariate model. $\mathrm{R}^{2}$ for each variable in linear regression model 3 was

553 determined using the relaimpo package (68). Mcfadden's Pseudo- $\mathrm{R}^{2}$ for each variable in model

5543 was calculated for logistic regression using full models minus the variable of interest.

555

556

557

558

559

560

561

562

563

564

565

566

567

568

569

570

571

572 
medRxiv preprint doi: https://doi.org/10.1101/2020.06.17.20127407; this version posted June 22, 2020. The copyright holder for this preprint (which was not certified by peer review) is the author/funder, who has granted medRxiv a license to display the preprint in perpetuity.

All rights reserved. No reuse allowed without permission.

\section{References}

1. Bisgaard $\mathrm{H}$, Bønnelykke K. Long-term studies of the natural history of asthma in childhood. $\mathrm{J}$ Allergy Clin Immunol. 2010 Aug;126(2):187-99.

2. Jaakkola JJK, Ahmed P, leromnimon A, Goepfert P, Laiou E, Quansah R, et al. Preterm delivery and asthma: a systematic review and meta-analysis. J Allergy Clin Immunol. 2006 Oct;118(4):823-30.

3. Mu M, Ye S, Bai M, Liu G, Tong Y, Wang S, et al. Birth weight and subsequent risk of asthma: a systematic review and meta-analysis. Heart Lung Circ. 2014 Jun;23(6):511-9.

4. Thavagnanam S, Fleming J, Bromley A, Shields MD, Cardwell CR. A meta-analysis of the association between Caesarean section and childhood asthma. Clin Exp Allergy. 2008 Apr;38(4):629-33.

5. Xu X, Li Y, Sheng Y, Liu J, Tang L, Chen Z. Effect of low birth weight on childhood asthma: a meta-analysis. BMC Pediatr. 2014 Oct 23,;14:275.

6. Krishnan L, Guilbert LJ, Russell AS, Wegmann TG, Mosmann TR, Belosevic M. Pregnancy impairs resistance of C57BL/6 mice to Leishmania major infection and causes decreased antigen-specific IFN-gamma response and increased production of T helper 2 cytokines. $J$ Immunol. 1996 Jan 15,;156(2):644-52.

7. Lin H, Mosmann TR, Guilbert L, Tuntipopipat S, Wegmann TG. Synthesis of T helper 2-type cytokines at the maternal-fetal interface. J Immunol. 1993 Nov 01,;151(9):4562-73.

8. Wegmann TG, Lin H, Guilbert L, Mosmann TR. Bidirectional cytokine interactions in the maternal-fetal relationship: is successful pregnancy a TH2 phenomenon? Immunol Today. 1993 Jul;14(7):353-6.

9. Forestier F, Daffos F, Catherine N, Renard M, Andreux JP. Developmental hematopoiesis in normal human fetal blood. Blood. 1991 Jun 01,;77(11):2360-3.

10. Glasser L, Sutton N, Schmeling M, Machan JT. A comprehensive study of umbilical cord blood cell developmental changes and reference ranges by gestation, gender and mode of delivery. J Perinatol. 2015 Jul;35(7):469-75.

11. Dinarello CA. IL-18: A TH1-inducing, proinflammatory cytokine and new member of the IL-1 family. J Allergy Clin Immunol. 1999 Jan;103(1 Pt 1):11-24.

12. Sims JE, Smith DE. The IL-1 family: regulators of immunity. Nat Rev Immunol. 2010 Feb;10(2):89-102.

13. Schorer M, Kuchroo VK, Joller N. Role of Co-stimulatory Molecules in T Helper Cell Differentiation. Adv Exp Med Biol. 2019;1189:153-77. 
medRxiv preprint doi: https://doi.org/10.1101/2020.06.17.20127407; this version posted June 22, 2020. The copyright holder for this preprint (which was not certified by peer review) is the author/funder, who has granted medRxiv a license to display the preprint in perpetuity.

All rights reserved. No reuse allowed without permission.

606

607

608

609

610

611

612

613

614

615

616

617

618

619

620

621

622

623

624

625

626

627

628

629

630

631

632

633

634

635

636

637

638

639

640

14. Gern JE, Brooks GD, Meyer P, Chang A, Shen K, Evans MD, et al. Bidirectional interactions between viral respiratory illnesses and cytokine responses in the first year of life. J Allergy Clin Immunol. 2006 Jan;117(1):72-8.

15. Ly NP, Rifas-Shiman SL, Litonjua AA, Tzianabos AO, Schaub B, Ruiz-Pérez B, et al. Cord blood cytokines and acute lower respiratory illnesses in the first year of life. Pediatrics. 2007 Jan;119(1):171.

16. Xu C, Söderhäll C, Bustamante M, Baïz N, Gruzieva O, Gehring U, et al. DNA methylation in childhood asthma: an epigenome-wide meta-analysis. Lancet Respir Med. 2018 05;6(5):379-88.

17. Reese SE, Xu C, den Dekker HT, Lee MK, Sikdar S, Ruiz-Arenas C, et al. Epigenome-wide meta-analysis of DNA methylation and childhood asthma. J Allergy Clin Immunol. 2018 Dec 21,.

18. Wenzel SE. Asthma phenotypes: the evolution from clinical to molecular approaches. Nat Med. 2012 May 04,;18(5):716-25.

19. Litonjua AA, Carey VJ, Laranjo N, Stubbs BJ, Mirzakhani H, O'Connor GT, et al. Six-Year Follow-up of a Trial of Antenatal Vitamin D for Asthma Reduction. N Engl J Med. 202002 $06, ; 382(6): 525-33$.

20. Azad MB, Coneys JG, Kozyrskyj AL, Field CJ, Ramsey CD, Becker AB, et al. Probiotic supplementation during pregnancy or infancy for the prevention of asthma and wheeze: systematic review and meta-analysis. BMJ. 2013 Dec 04,;347:f6471.

21. Bukowski R, Sadovsky Y, Goodarzi H, Zhang H, Biggio JR, Varner M, et al. Onset of human preterm and term birth is related to unique inflammatory transcriptome profiles at the maternal fetal interface. PeerJ. 2017;5:e3685.

22. Edlow AG, Hui L, Wick HC, Fried I, Bianchi DW. Assessing the fetal effects of maternal obesity via transcriptomic analysis of cord blood: a prospective case-control study. BJOG. 2016 Jan;123(2):180-9.

23. Kallionpää H, Laajala E, Öling V, Härkönen T, Tillmann V, Dorshakova NV, et al. Standard of hygiene and immune adaptation in newborn infants. Clin Immunol. 2014 Nov;155(1):136-47.

24. Mason E, Tronc G, Nones K, Matigian N, Kim J, Aronow BJ, et al. Maternal influences on the transmission of leukocyte gene expression profiles in population samples from Brisbane, Australia. PLoS ONE. 2010 Dec 31,;5(12):e14479.

25. Rager JE, Bailey KA, Smeester L, Miller SK, Parker JS, Laine JE, et al. Prenatal arsenic exposure and the epigenome: altered microRNAs associated with innate and adaptive immune signaling in newborn cord blood. Environ Mol Mutagen. 2014 Apr;55(3):196-208.

26. Smith CL, Dickinson P, Forster T, Craigon M, Ross A, Khondoker MR, et al. Identification of a human neonatal immune-metabolic network associated with bacterial infection. Nat Commun. 2014 Aug 14,;5:4649. 
medRxiv preprint doi: https://doi.org/10.1101/2020.06.17.20127407; this version posted June 22, 2020. The copyright holder for this preprint (which was not certified by peer review) is the author/funder, who has granted medRxiv a license to display the preprint in perpetuity.

All rights reserved. No reuse allowed without permission.

641

642

643

644

645

646

647

648

649

650

651

652

653

654

655

656

657

658

659

660

661

662

663

664

665

666

667

668

669

670

671

672

673

674

675

27. Stünkel W, Pan H, Chew SB, Tng E, Tan JH, Chen L, et al. Transcriptome changes affecting Hedgehog and cytokine signalling in the umbilical cord: implications for disease risk. PLoS ONE. 2012;7(7):e39744.

28. Turan N, Ghalwash MF, Katari S, Coutifaris C, Obradovic Z, Sapienza C. DNA methylation differences at growth related genes correlate with birth weight: a molecular signature linked to developmental origins of adult disease? BMC Med Genomics. 2012 Apr 12,;5:10.

29. Votavova H, Dostalova Merkerova M, Fejglova K, Vasikova A, Krejcik Z, Pastorkova A, et al. Transcriptome alterations in maternal and fetal cells induced by tobacco smoke. Placenta. 2011 Oct;32(10):763-70.

30. Votavova H, Dostalova Merkerova M, Krejcik Z, Fejglova K, Vasikova A, Pastorkova A, et al. Deregulation of gene expression induced by environmental tobacco smoke exposure in pregnancy. Nicotine Tob Res. 2012 Sep;14(9):1073-82.

31. Winckelmans E, Vrijens K, Tsamou M, Janssen BG, Saenen ND, Roels HA, et al. Newborn sex-specific transcriptome signatures and gestational exposure to fine particles: findings from the ENVIRONAGE birth cohort. Environ Health. 201706 05,;16(1):52.

32. Olin A, Henckel E, Chen Y, Lakshmikanth T, Pou C, Mikes J, et al. Stereotypic Immune System Development in Newborn Children. Cell. 2018 Aug 23,;174(5):1277,1292.e14.

33. Bohlin J, Håberg SE, Magnus P, Reese SE, Gjessing HK, Magnus MC, et al. Prediction of gestational age based on genome-wide differentially methylated regions. Genome Biol. 201610 07,;17(1):207.

34. Uhlen M, Oksvold P, Fagerberg L, Lundberg E, Jonasson K, Forsberg M, et al. Towards a knowledge-based Human Protein Atlas. Nat Biotechnol. 2010 Dec;28(12):1248-50.

35. Monaco G, Lee B, Xu W, Mustafah S, Hwang YY, Carré C, et al. RNA-Seq Signatures Normalized by mRNA Abundance Allow Absolute Deconvolution of Human Immune Cell Types. Cell Rep. 201902 05,;26(6):1627,1640.e7.

36. Zhu Y, Gong K, Denholtz M, Chandra V, Kamps MP, Alber F, et al. Comprehensive characterization of neutrophil genome topology. Genes Dev. 201701 15,;31(2):141-53.

37. Grassi L, Pourfarzad F, Ullrich S, Merkel A, Were F, Carrillo-de-Santa-Pau E, et al. Dynamics of Transcription Regulation in Human Bone Marrow Myeloid Differentiation to Mature Blood Neutrophils. Cell Rep. 201809 04,;24(10):2784-94.

38. Rørvig S, Østergaard O, Heegaard NHH, Borregaard N. Proteome profiling of human neutrophil granule subsets, secretory vesicles, and cell membrane: correlation with transcriptome profiling of neutrophil precursors. J Leukoc Biol. 2013 Oct;94(4):711-21.

39. Lawrence SM, Corriden R, Nizet V. Age-Appropriate Functions and Dysfunctions of the Neonatal Neutrophil. Front Pediatr. 2017;5:23. 
medRxiv preprint doi: https://doi.org/10.1101/2020.06.17.20127407; this version posted June 22, 2020. The copyright holder for this preprint (which was not certified by peer review) is the author/funder, who has granted medRxiv a license to display the preprint in perpetuity.

All rights reserved. No reuse allowed without permission.

40. Klimenkova O, Ellerbeck W, Klimiankou M, Ünalan M, Kandabarau S, Gigina A, et al. A lack of secretory leukocyte protease inhibitor (SLPI) causes defects in granulocytic differentiation. Blood. 2014 Feb 20,;123(8):1239-49.

41. Lekstrom-Himes JA, Dorman SE, Kopar P, Holland SM, Gallin JI. Neutrophil-specific granule deficiency results from a novel mutation with loss of function of the transcription factor CCAAT/enhancer binding protein epsilon. J Exp Med. 1999 Jun 07,;189(11):1847-52.

42. Jones SA, Horiuchi S, Topley N, Yamamoto N, Fuller GM. The soluble interleukin 6 receptor: mechanisms of production and implications in disease. FASEB J. 2001 Jan;15(1):4358.

43. Read CB, Kuijper JL, Hjorth SA, Heipel MD, Tang X, Fleetwood AJ, et al. Cutting Edge: identification of neutrophil PGLYRP1 as a ligand for TREM-1. J Immunol. 2015 Feb $15, ; 194(4): 1417-21$.

44. Kashyap DR, Wang M, Liu L, Boons G, Gupta D, Dziarski R. Peptidoglycan recognition proteins kill bacteria by activating protein-sensing two-component systems. Nat Med. 2011 Jun;17(6):676-83.

45. Liu C, Gelius E, Liu G, Steiner H, Dziarski R. Mammalian peptidoglycan recognition protein binds peptidoglycan with high affinity, is expressed in neutrophils, and inhibits bacterial growth. J Biol Chem. 2000 Aug 11,;275(32):24490-9.

46. Wang M, Liu L, Wang S, Li X, Lu X, Gupta D, et al. Human peptidoglycan recognition proteins require zinc to kill both gram-positive and gram-negative bacteria and are synergistic with antibacterial peptides. J Immunol. 2007 Mar 01,;178(5):3116-25.

47. Dziarski R, Gupta D. The peptidoglycan recognition proteins (PGRPs). Genome Biol. 2006;7(8):232.

48. Park SY, Jing X, Gupta D, Dziarski R. Peptidoglycan recognition protein 1 enhances experimental asthma by promoting Th2 and Th17 and limiting regulatory $T$ cell and plasmacytoid dendritic cell responses. J Immunol. 2013 Apr 01,;190(7):3480-92.

49. Yao X, Gao M, Dai C, Meyer KS, Chen J, Keeran KJ, et al. Peptidoglycan recognition protein 1 promotes house dust mite-induced airway inflammation in mice. Am J Respir Cell Mol Biol. 2013 Dec;49(6):902-11.

50. Luo Q, Li X, Zhang L, Yao F, Deng Z, Qing C, et al. Serum PGLYRP-1 is a highly discriminatory biomarker for the diagnosis of rheumatoid arthritis. Mol Med Rep. 2019 Jan;19(1):589-94.

51. Rohatgi A, Ayers CR, Khera A, McGuire DK, Das SR, Matulevicius S, et al. The association between peptidoglycan recognition protein-1 and coronary and peripheral atherosclerosis: Observations from the Dallas Heart Study. Atherosclerosis. 2009 Apr;203(2):569-75. 
medRxiv preprint doi: https://doi.org/10.1101/2020.06.17.20127407; this version posted June 22, 2020. The copyright holder for this preprint (which was not certified by peer review) is the author/funder, who has granted medRxiv a license to display the preprint in perpetuity.

All rights reserved. No reuse allowed without permission.

52. Bui DS, Lodge CJ, Burgess JA, Lowe AJ, Perret J, Bui MQ, et al. Childhood predictors of lung function trajectories and future COPD risk: a prospective cohort study from the first to the sixth decade of life. Lancet Respir Med. 2018 07;6(7):535-44.

53. Lo DK, Beardsmore CS, Roland D, Richardson M, Yang Y, Danvers L, et al. Lung function and asthma control in school-age children managed in UK primary care: a cohort study. Thorax. 2020 Feb;75(2):101-7.

54. Piccioni $P$, Tassinari R, Carosso A, Carena $C$, Bugiani $M$, Bono R. Lung function changes from childhood to adolescence: a seven-year follow-up study. BMC Pulm Med. 2015 Apr $03, ; 15: 31$.

55. Turturice BA, McGee HS, Oliver B, Baraket M, Nguyen BT, Ascoli C, et al. Atopic asthmatic immune phenotypes associated with airway microbiota and airway obstruction. PLoS ONE. 2017;12(10):e0184566.

56. Tse SM, Gold DR, Sordillo JE, Hoffman EB, Gillman MW, Rifas-Shiman SL, et al. Diagnostic accuracy of the bronchodilator response in children. J Allergy Clin Immunol. 2013 Sep;132(3):554,559.e5.

57. Oken E, Baccarelli AA, Gold DR, Kleinman KP, Litonjua AA, De Meo D, et al. Cohort profile: project viva. Int J Epidemiol. 2015 Feb;44(1):37-48.

58. Miller MR, Hankinson J, Brusasco V, Burgos F, Casaburi R, Coates A, et al. Standardisation of spirometry. Eur Respir J. 2005 Aug;26(2):319-38.

59. Koenig MD, Klikuszowian E, O'Brien KO, Pauls H, Steffen A, DeMartelly V, et al. Prepregnancy Obesity Is Not Associated with Iron Utilization during the Third Trimester. J Nutr. 2020 Mar 28,.

60. Schaub B, Tantisira KG, Gibbons FK, He H, Litonjua AA, Gillman MW, et al. Fetal cord blood: aspects of heightened immune responses. J Clin Immunol. 2005 Jul;25(4):329-37.

61. Davis S, Meltzer PS. GEOquery: a bridge between the Gene Expression Omnibus (GEO) and BioConductor. Bioinformatics. 2007 Jul 15,;23(14):1846-7.

62. GeneMeta: MetaAnalysis for High Throughput Experiments [Internet].; 2018 [cited Feb 21, 2019]. Available from: http://bioconductor.org/packages/GeneMeta/.

63. Subramanian A, Tamayo P, Mootha VK, Mukherjee S, Ebert BL, Gillette MA, et al. Gene set enrichment analysis: a knowledge-based approach for interpreting genome-wide expression profiles. Proc Natl Acad Sci U S A. 2005 Oct 25,;102(43):15545-50.

64. Patro R, Duggal G, Love MI, Irizarry RA, Kingsford C. Salmon provides fast and bias-aware quantification of transcript expression. Nat Methods. 2017 Apr;14(4):417-9.

65. Soneson C, Love MI, Robinson MD. Differential analyses for RNA-seq: transcript-level estimates improve gene-level inferences. F1000Res. 2015;4:1521. 
medRxiv preprint doi: https://doi.org/10.1101/2020.06.17.20127407; this version posted June 22, 2020. The copyright holder for this preprint (which was not certified by peer review) is the author/funder, who has granted medRxiv a license to display the preprint in perpetuity.

All rights reserved. No reuse allowed without permission.

746

747

748

749

750

751

752

753

754

755

756

757

758

759

760

761

762

763

764

765

766

767

768

769

770

771

772

66. Love MI, Huber W, Anders S. Moderated estimation of fold change and dispersion for RNAseq data with DESeq2. Genome Biol. 2014;15(12):550.

67. Szklarczyk D, Gable AL, Lyon D, Junge A, Wyder S, Huerta-Cepas J, et al. STRING v11: protein-protein association networks with increased coverage, supporting functional discovery in genome-wide experimental datasets. Nucleic Acids Res. 201901 08,;47(D1):D607-13.

68. Groemping U. Relative Importance for Linear Regression in R: The Package relaimpo. Journal of Statistical Software. $2006 / 09 / 01 ; 17(1): 1-27$.

3

4

5


medRxiv preprint doi: https://doi.org/10.1101/2020.06.17.20127407; this version posted June 22,2020 . The copyright holder for this preprint (which was not certified by peer review) is the author/funder, who has granted medRxiv a license to display the preprint in perpetuity.

All rights reserved. No reuse allowed without permission.

Figure 1. Overview of analytic approach used to identify biological risk for pediatric asthma. (A) Previously described perinatal risk factors for development of pediatric asthma: preterm birth, low birthweight, male, and maternal obesity. (B) Flow diagram of search, inclusion, exclusion, and univariate testing for transcriptomic analysis. (C) Cohorts, types of biosamples, and outcomes used for validation.

Figure 2. Pooled meta-analysis z-scores identify gene expression signatures related to asthma risk. Significant (FDR $<1 \%$ ) genes and gene sets are colored by their association with either higher (red) or lower (blue) risk. (A) Volcano plots of gene expression for univariate analyses. Top 10 most significant genes labeled. (B) Word clouds of GO terms significantly enriched (FDR $<1 \%$ ) using the pooled $\mathrm{z}$-score as pre-ranked list for GSEA. (C) Protein coding transcripts per million reads (pTPM) in peripheral blood cells (Human Protein Atlas and Monaco et al., $(34,35)$ ) relative to pooled $z$-score. Each line represents one cell type; neutrophils highlighted in orange. (D) Spearman's correlation between pooled z-statistic and individual analyses (diamonds). Average Spearman's correlations between individual analyses and combination of all other analyses (circle), SD indicated by error bars.

790

791

792

793

794

795

796

797

798

799

800

801

802

803

804

805

806

807

808

809

810

811

812

813

814

815

816

817

818

819

820

821

Figure 3. Validation cohort identifies gene signature associated with pediatric asthma risk factors. Color labeling indicating association with either higher (red) or lower (blue) risk of pediatric asthma development (A) Dot-plot demonstrating validation between meta-analysis Pooled z-score and UIH cohort mRNAseq z-score. Colored and labeled dots indicate those with non-parametric replication score greater than 3 and 4, respectively. (B-C) Association between number of risk factors or individual risk factors and eigenvalue of gene signature (validation score $>3)$, UIH Cohort.

Figure 4. Cellular and proteomic differences associated with pediatric asthma risk factors. (A-C) Re-analysis of publicly available data from Olin et al. (32). (A) Percentage of neutrophils in cord blood (transformed using centered log-ratios, CLR) correlated with number of risk factors. Pearson's Correlation $(R)$ and Bonferroni adjusted $p$-value reported. (B) Pearson's correlation coefficients $(R)$ for plasma-protein concentration and number of risk factors distributed based on risk association of proteins as per Figure 3. Corresponding mRNA from CBMCs were identified for low risk associated proteins (blue) and no risk associated proteins (dark grey). Most significant negative protein correlations with neutrophil-enriched mRNA (Human Protein Atlas, (34)) are notated. Proteins identified in previous analysis without corresponding mRNA shown light grey. (C) Heatmap of Pearson's correlations between neutrophils and neutrophil-derived proteins identified in (B). (D) Association between PGLYRP-1 umbilical cord serum concentration, PGLYRP-1 CBMC mRNA, and number of risk factors in UIH cohort.

Figure 5. Increased umbilical cord blood serum PGLYRP-1 is associated with increased FEV1/FVC and reduced odds of pediatric asthma. Samples and data derived from a subset of Project Viva $(n=358)$. Odds ratio and coefficient estimates are based on one standard deviation increase in serum proteins (PGLYRP-1, sIL6R $)$. Error bars indicate 95\% Cl. Adjusted model covariates: gestational age, birthweight adjusted for gestational age and sex, mode of delivery, child's sex, child's race/ethnicity, maternal pre-pregnancy BMI, maternal level of education, maternal atopy, antibiotic exposure during pregnancy, and early life smoke exposure. (A) PGLYRP-1 and sIL6Ra concentrations in umbilical cord blood serum associations with current asthma at mid-childhood and early-teenage time points (determined by questionnaire responses). (B) PGLYRP-1 and slL6Ra concentration in umbilical cord blood serum associations with 
medRxiv preprint doi: https://doi.org/10.1101/2020.06.17.20127407; this version posted June 22, 2020. The copyright holder for this preprint (which was not certified by peer review) is the author/funder, who has granted medRxiv a license to display the preprint in perpetuity. All rights reserved. No reuse allowed without permission.

822 FEV1/FVCx100 at mid-childhood and early-teenage follow-ups. ${ }^{* \star *} p<0.001,{ }^{* *} p<0.01,{ }^{*} p<0.05$, $823 \quad \# p<0.1$

824

825

826

827

828

829

830

831

832

833

834

835

836

837

838

839

840

841

842

843

844

845

846

847

848

849

850

851

852

853

854

855

856

857

858

859

860

861

862

863

864

865

866

867

868

869

870

871 
medRxiv preprint doi: https://doi.org/10.1101/2020.06.17.20127407; this version posted June 22, 2020. The copyright holder for this preprint (which was not certified by peer review) is the author/funder, who has granted medRxiv a license to display the preprint in perpetuity.

All rights reserved. No reuse allowed without permission.

\section{Figures}

A

Lower Risk

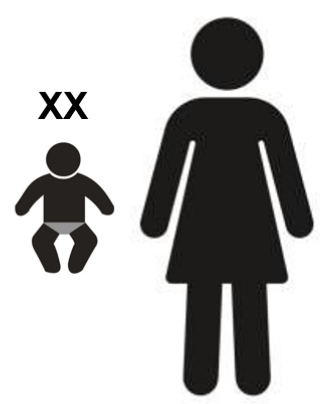

Higher Risk

Vs.

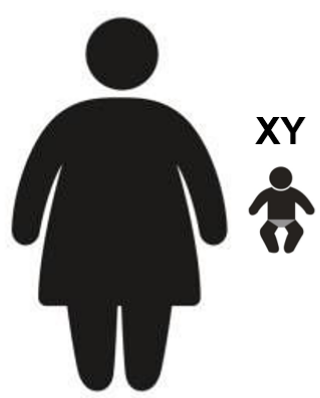

B

NCBI GEO Data Sets

Search: "Cord Blood" AND "Homo sapiens"[porgn:_ttxid9606] Filter: Expression Profiling by Array

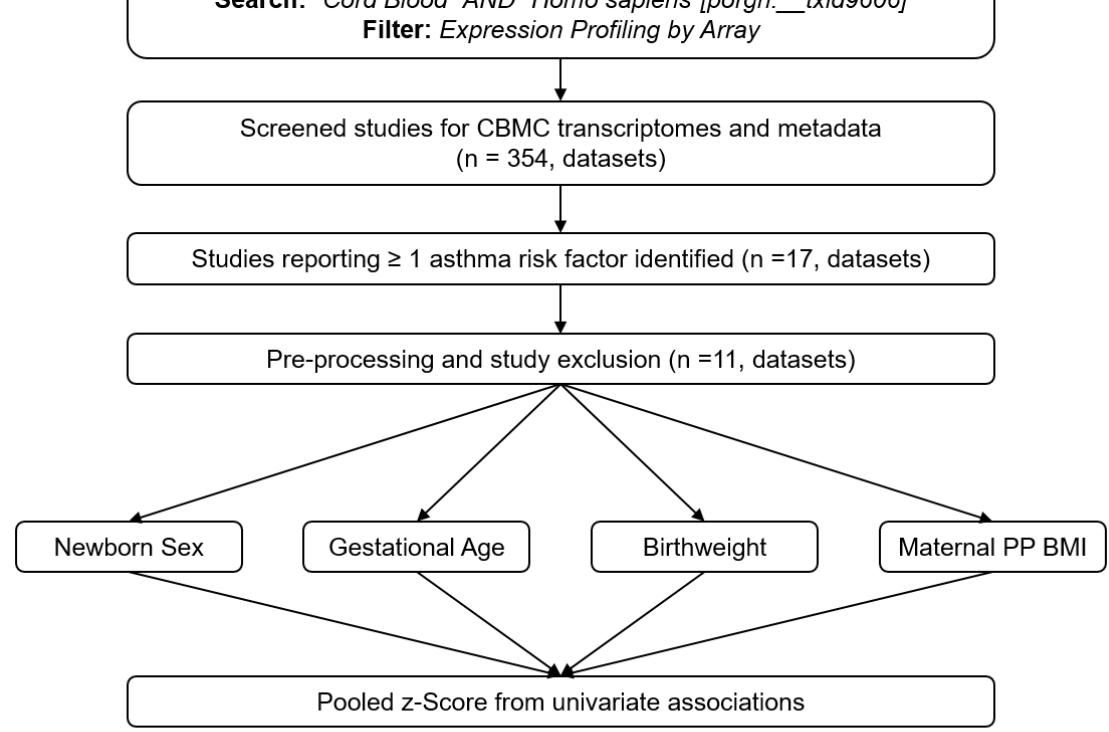

C

\section{Validation}

mRNA, UIH Cohort, Number of Risk Factors, $\mathrm{n}=30$

Protein, Olin et al, Number of Risk Factors, $n=50$

Protein, UIH Cohort, Number of Risk Factors, $n=30$

Outcomes

Protein, Project Viva, $\mathrm{n}=358$

Mid-Childhood (Median Age 7.7 years)

Early-Teenage (Median Age $\sim 12.3$ years)

Asthma: Physician Diagnosed \pm Wheezing or Medication Obstruction: FEV1/FVCx100 and BDR

Figure 1. Overview of analytic approach used to identify biological risk for pediatric asthma. (A) Previously described perinatal risk factors for development of pediatric asthma: preterm birth, low birthweight, male, and maternal obesity. (B) Flow diagram of search, inclusion, exclusion, and univariate testing for transcriptomic analysis. (C) Cohorts, types of biosamples, and outcomes used for validation. 
medRxiv preprint doi: https://doi.org/10.1101/2020.06.17.20127407; this version posted June 22, 2020. The copyright holder for this preprint (which was not certified by peer review) is the author/funder, who has granted medRxiv a license to display the preprint in perpetuity. All rights reserved. No reuse allowed without permission.
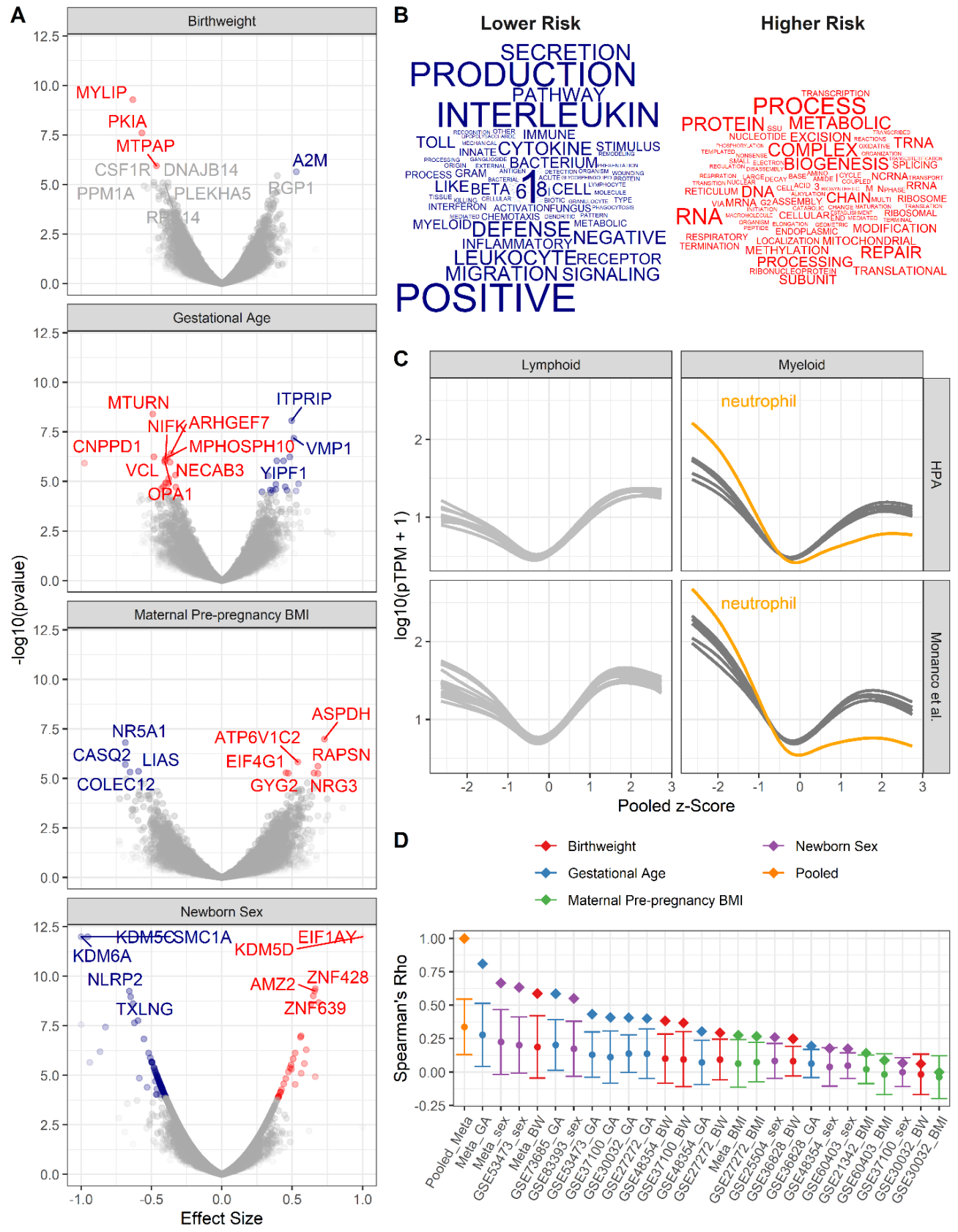

Figure 2. Pooled meta-analysis z-scores identify gene expression signatures related to asthma risk. Significant (FDR $<1 \%)$ genes and gene sets are colored by their association with either higher (red) or lower (blue) risk. (A) Volcano plots of gene expression for univariate analyses. Top 10 most significant genes labeled. (B) Word clouds of GO terms significantly enriched (FDR $<1 \%)$ using the pooled $z$-score as pre-ranked list for GSEA. (C) Protein coding transcripts per million reads (pTPM) in peripheral blood cells (Human Protein Atlas and Monaco et al., $(34,35))$ relative to pooled $z$-score. Each line represents one cell type; neutrophils highlighted in orange. (D) Spearman's correlation between pooled z-statistic and individual analyses (diamonds). Average Spearman's correlations between individual analyses and combination of all other analyses (circle), SD indicated by error bars. 
A

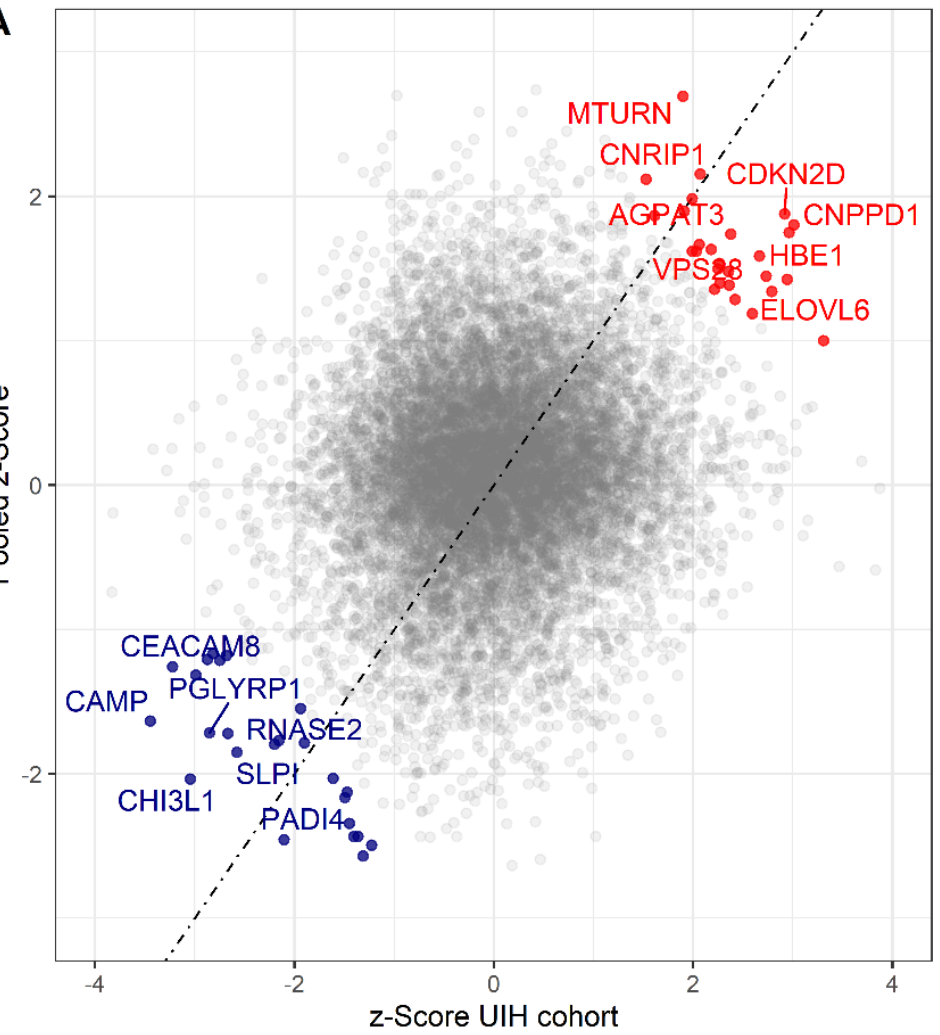

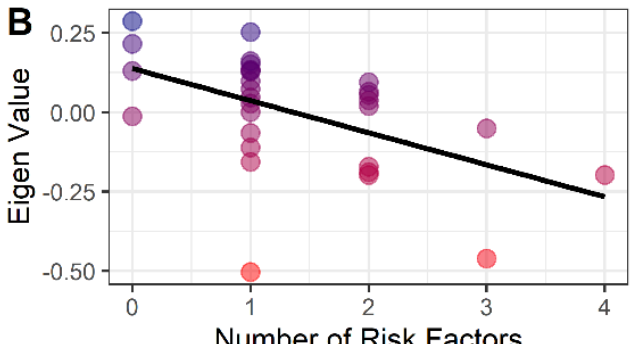

Number of Risk Factors
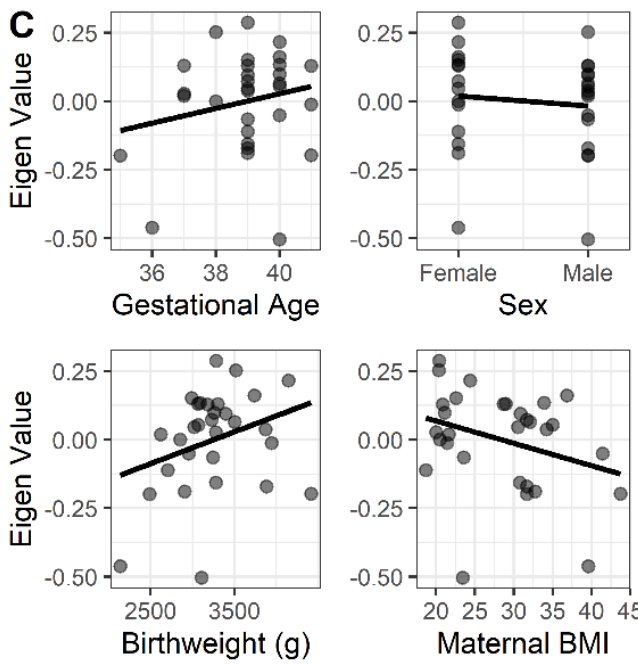

Figure 3. Validation cohort identifies gene signature associated with pediatric asthma risk factors. Color labeling indicating association with either higher (red) or lower (blue) risk of pediatric asthma development (A) Dot-plot demonstrating validation between meta-analysis Pooled z-score and UIH cohort mRNAseq z-score. Colored and labeled dots indicate those with non-parametric replication score greater than 3 and 4, respectively. (B-C) Association between number of risk factors or individual risk factors and eigenvalue of gene signature (validation score $>3)$, UIH Cohort. 

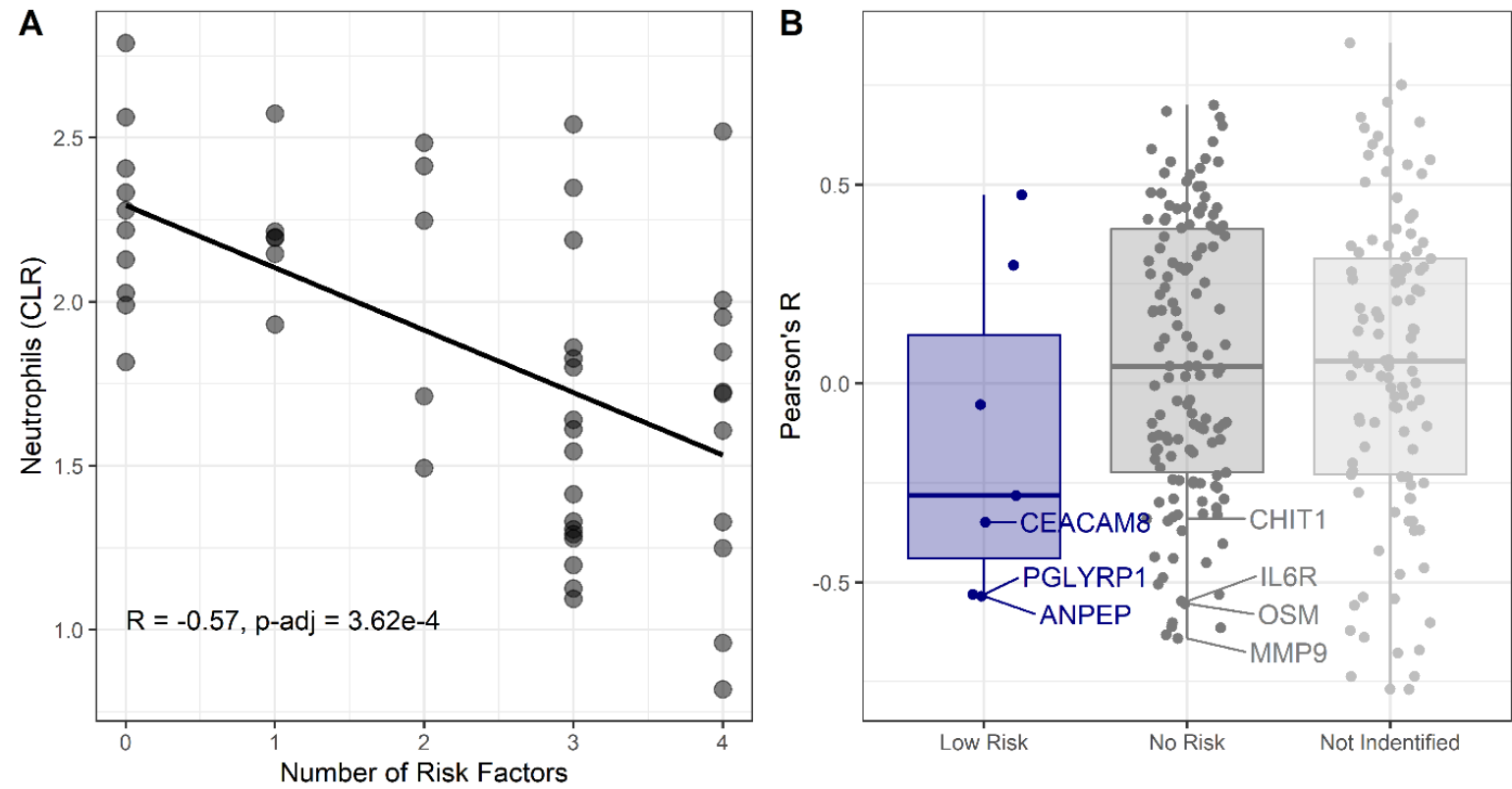

C

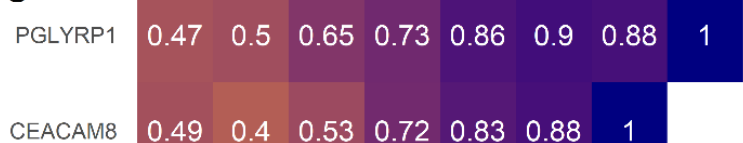

$\begin{array}{lllllllll}\text { CEACAM8 } & 0.49 & 0.4 & 0.53 & 0.72 & 0.83 & 0.88 & 1\end{array}$

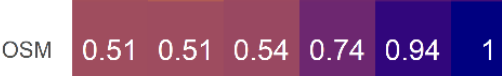

MMP9

$$
\text { CHIT1 }
$$
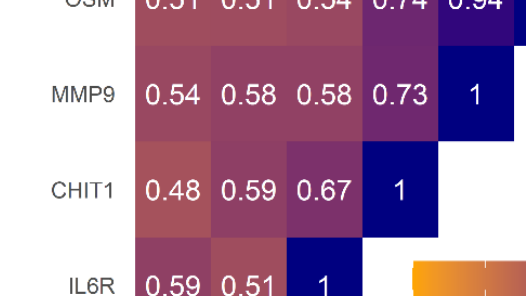

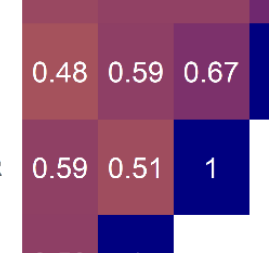

ANPEP
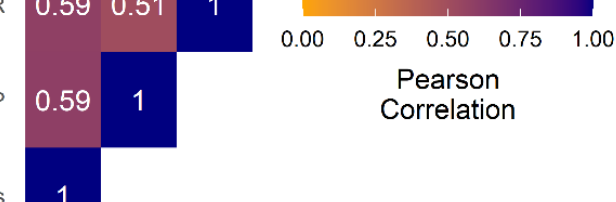

Figure 4. Cellular and proteomic differences associated with pediatric asthma risk factors. (A-C) Re-analysis of publicly available data from Olin et al. (32). (A) Percentage of neutrophils in cord blood (transformed using centered log-ratios, CLR) correlated with number of risk factors. Pearson's Correlation (R) and Bonferroni adjusted p-value reported. (B) Pearson's correlation coefficients $(R)$ for plasma-protein concentration and number of risk factors distributed based on risk association of proteins as per Figure 3. Corresponding mRNA from CBMCs were identified for low risk associated proteins (blue) and no risk associated proteins (dark grey). Most significant negative protein correlations with neutrophil-enriched mRNA (Human Protein Atlas, (34)) are notated. Proteins identified in previous analysis without corresponding mRNA shown light grey. (C) Heatmap of Pearson's correlations between neutrophils and neutrophil-derived proteins identified in (B). (D) Association between PGLYRP-1 umbilical cord serum concentration, PGLYRP-1 CBMC mRNA, and number of risk factors in UIH cohort. 

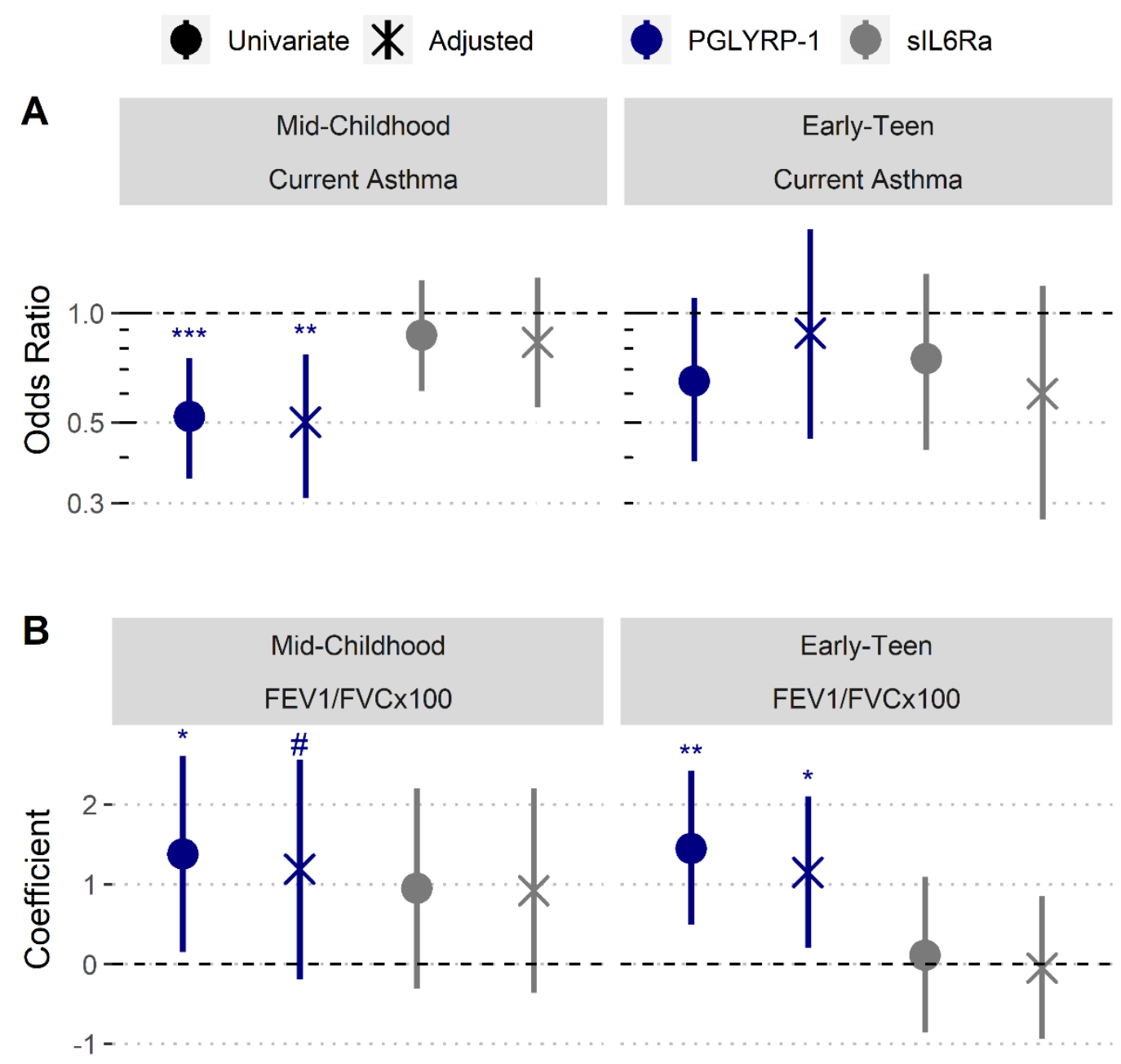

Figure 5. Increased umbilical cord blood serum PGLYRP-1 is associated with increased FEV1/FVC and reduced odds of pediatric asthma. Samples and data derived from a subset of Project Viva $(n=358)$. Odds ratio and coefficient estimates are based on one standard deviation increase in serum proteins (PGLYRP-1, sIL6Ra). Error bars indicate 95\% Cl. Adjusted model covariates: gestational age, birthweight adjusted for gestational age and sex, mode of delivery, child's sex, child's race/ethnicity, maternal pre-pregnancy BMI, maternal level of education, maternal atopy, antibiotic exposure during pregnancy, and early life smoke exposure. (A) PGLYRP-1 and sIL6Ra concentrations in umbilical cord blood serum associations with current asthma at mid-childhood and early-teenage time points (determined by questionnaire responses). (B) PGLYRP-1 and slL6Ra concentration in umbilical cord blood serum associations with FEV1/FVCx100 at mid-childhood and early-teenage follow-ups. ${ }^{* * *} p<0.001,{ }^{* *} p<0.01,{ }^{*} p<0.05$, $\# p<0.1$ 
medRxiv preprint doi: https://doi.org/10.1101/2020.06.17.20127407; this version posted June 22, 2020. The copyright holder for this preprint (which was not certified by peer review) is the author/funder, who has granted medRxiv a license to display the preprint in perpetuity.

\section{Tables}

Table 1. GSE Data Sets Used for Meta-Analysis

Table 2. Univariate Associations between Cord Blood Serum Proteins and Covariates

Table 3. Association between Cord Blood Serum Proteins and Asthma Outcomes

Table 4. Association between Cord Blood Serum Proteins and Pulmonary Function Tests 
Table 1. GSE Data Sets Used for Meta-Analyses

\begin{tabular}{|c|c|c|c|c|c|c|c|}
\hline GSE & GPL & $\mathbf{N}$ & $\begin{array}{l}\text { Newborn } \\
\text { Sex }\end{array}$ & $\begin{array}{l}\text { Gestational } \\
\text { Age }\end{array}$ & Birthweight & $\begin{array}{l}\text { Maternal Pre- } \\
\text { Pregnancy BMI }\end{array}$ & Title \\
\hline GSE21342 & GPL6947 & 37 & & & & + & $\begin{array}{c}\text { Maternal influences on the transmission of leukocyte gene expression } \\
\text { profiles in population samples }\end{array}$ \\
\hline GSE25504 & GPL570 & 20 & + & & & & $\begin{array}{l}\text { Whole blood mRNA expression profiling of host molecular networks in } \\
\text { neonatal sepsis }\end{array}$ \\
\hline GSE27272 & GPL6883 & 64 & & + & + & + & $\begin{array}{l}\text { Comprehensive Study of Tobacco Smoke-Related Transcriptome Alterations } \\
\text { in Maternal and Fetal Cells }\end{array}$ \\
\hline GSE30032 & GPL6883 & 47 & & + & + & + & $\begin{array}{l}\text { Deregulation of Gene Expression induced by Environmental Tobacco Smoke } \\
\text { Exposure in Pregnancy }\end{array}$ \\
\hline GSE36828 & GPL6947 & 48 & & + & + & & $\begin{array}{c}\text { Genome-wide analysis of gene expression levels in placenta and cord blood } \\
\text { samples from newborns babies }\end{array}$ \\
\hline GSE37100 & GPL14550 & 38 & + & + & + & & $\begin{array}{l}\text { Transcriptome changes affecting hedgehog and cytokine signalling in the } \\
\text { umbilical cord in late pregnancy: implications for disease risk }\end{array}$ \\
\hline GSE48354 & GPL16686 & 38 & + & + & + & & $\begin{array}{l}\text { Prenatal arsenic exposure and the epigenome: altered gene expression } \\
\text { profiles in newborn cord blood }\end{array}$ \\
\hline GSE53473 & GPL13667 & 128 & + & + & & & Standard of hygiene and immune adaptation in newborn infants \\
\hline GSE60403 & GPL570 & 16 & + & & & + & The obese fetal transcriptome \\
\hline GSE73685 & GPL6244 & 23 & & + & & & $\begin{array}{l}\text { Unique inflammatory transcriptome profiles at the maternal fetal interface } \\
\text { and onset of human preterm and term birth }\end{array}$ \\
\hline GSE83393 & GPL17077 & 146 & + & & & & $\begin{array}{c}\text { Newborn Sex-specific Transcriptome Signatures and Gestational Exposure } \\
\text { to Fine Particles: Findings from the ENVIRONAGE Birth Cohort }\end{array}$ \\
\hline & $\mathbf{N}$ & 605 & 386 & 386 & 235 & 164 & \\
\hline
\end{tabular}


medRxiv preprint doi: https://doi.org/10.1101/2020.06.17.20127407; this version posted June 22,2020 . The copyright holder for this preprint (which was not certified by peer review) is the author/funder, who has granted medRxiv a license to display the preprint in perpetuity.

Table 2. Univariate Associations between Demographics and Serum Proteins

\begin{tabular}{|c|c|c|c|c|}
\hline & UIH ( $n=$ & & Project Viva ( & 358) \\
\hline & $\beta(95 \% \mathrm{Cl})$ & p-value & $\beta(95 \% \mathrm{Cl})$ & p-value \\
\hline PGLYRP-1 Z-Score* & & & & \\
\hline Maternal Race: White (ref) & 0 (ref) & & 0 (ref) & \\
\hline Maternal Race: Black & $0.01(-0.83,0.86)$ & 0.97 & $0.15(-0.16,0.46)$ & 0.34 \\
\hline Maternal Race: Hispanic & $1.03(0.05,2.01)$ & 0.04 & $0.40(-0.07,0.86)$ & 0.10 \\
\hline Maternal Race: Other & $1.54(-0.46,3.54)$ & 0.12 & $0.10(-0.25,0.46)$ & 0.57 \\
\hline Maternal Atopy & $-0.14(-0.92,0.64)$ & 0.72 & $0.06(-0.16,0.28)$ & 0.58 \\
\hline Maternal Pre-Pregnancy BMI & $-0.03(-0.09,0.02)$ & 0.25 & $0.01(-0.01,0.03)$ & 0.56 \\
\hline Maternal Smoking: Never (ref) & 0 (ref) & & 0 (ref) & \\
\hline Maternal Smoking: Former & $0.09(-0.92,1.12)$ & 0.84 & $-0.16(-0.44,0.11)$ & 0.25 \\
\hline Maternal Smoking: During Pregnancy & -- & -- & $-0.12(-0.47,0.22)$ & 0.48 \\
\hline Maternal College Graduate & $0.07(-0.80,0.93)$ & 0.87 & $-0.12(-0.340 .10)$ & 0.27 \\
\hline Any Antibiotic Use During Pregnancy & -- & -- & $0.20(-0.02,0.43)$ & 0.08 \\
\hline Gestational Age Weeks & $0.25(-0.01,0.51)$ & 0.06 & $0.12(0.06,0.19)$ & 0.0003 \\
\hline Birthweight adj GA and Sex (Z-score) & $0.33(-1.07,1.74)$ & 0.63 & $0.03(-0.09,0.14)$ & 0.66 \\
\hline Female & $0.39(-0.37,1.15)$ & 0.30 & $0.31(0.11,0.52)$ & 0.003 \\
\hline C-section & $-0.08(-0.89,0.74)$ & 0.85 & $-0.29(-0.55,-0.02)$ & 0.03 \\
\hline Child's Race: White (ref) & -- & -- & 0 (ref) & \\
\hline Child's Race: Black & -- & -- & $0.16(-0.14,0.46)$ & 0.31 \\
\hline Child's Race: Hispanic & -- & -- & $0.18(-0.31,0.68)$ & 0.46 \\
\hline Child's Race: Other & -- & -- & $0.06(-0.27,0.38)$ & 0.73 \\
\hline sIL6Ra Z-Score* & & & & \\
\hline Maternal Race: White (ref) & 0 (ref) & & 0 (ref) & \\
\hline Maternal Race: Black & $-1.04(-1.90,-0.19)$ & 0.02 & $-0.29(-0.60,0.02)$ & 0.07 \\
\hline Maternal Race: Hispanic & $-0.36(-1.34,0.62)$ & 0.45 & $0.34(-0.12,0.80)$ & 0.15 \\
\hline Maternal Race: Other & $0.4(-1.61,2.42)$ & 0.68 & $-0.03(-0.390 .32)$ & 0.85 \\
\hline Maternal Atopy & $-0.23(-1.01,0.54)$ & 0.55 & $-0.08(-0.30,0.14)$ & 0.47 \\
\hline Maternal Pre-Pregnancy BMI & $-0.04\left(\begin{array}{ll}-0.10 & 0.01\end{array}\right)$ & 0.12 & $0.00(-0.02,0.02)$ & 0.72 \\
\hline Maternal Smoking: Never (ref) & 0 (ref) & & 0 (ref) & \\
\hline Maternal Smoking: Former & $-0.90(-1.86,0.06)$ & 0.07 & $-0.23(-0.50,0.05)$ & 0.10 \\
\hline Maternal Smoking: During Pregnancy & - & -- & $-0.12(-0.46,0.22)$ & 0.48 \\
\hline Maternal College Graduate & $0.44(-0.41,1.29)$ & 0.29 & $-0.02(-0.24,0.19)$ & 0.84 \\
\hline Any Antibiotic Use During Pregnancy & -- & -- & $0.04(-0.19,0.26)$ & 0.76 \\
\hline Gestational Age Weeks & $-0.11(-0.39,0.17)$ & 0.43 & $-0.04(-0.10,0.03)$ & 0.29 \\
\hline Birthweight adj GA and Sex (Z-score) & $-0.15(-1.57,1.26)$ & 0.82 & $-0.07(-0.18,0.04)$ & 0.23 \\
\hline Female & $0.48(-0.28,1.23)$ & 0.21 & $0.05(-0.16,0.26)$ & 0.63 \\
\hline C-section & $-0.60(-1.38,0.18)$ & 0.12 & $-0.14(-0.41,0.12)$ & 0.29 \\
\hline Child's Race: White (ref) & -- & -- & 0 (ref) & \\
\hline Child's Race: Black & -- & -- & $-0.24(-0.54,0.05)$ & 0.11 \\
\hline Child's Race: Hispanic & -- & -- & $0.27(-0.22,0.76)$ & 0.28 \\
\hline Child's Race: Other & -- & -- & $0.02(-0.30,0.34)$ & 0.90 \\
\hline
\end{tabular}

*Serum protein concentrations for UIH and Project Viva were log10 transformed and converted into an internal Zscore. 
Table 3. Association Between Serum Protein Concentration and Asthma Outcomes



* Serum protein concentrations were log10 transformed and converted into an internal Z-score

$\dagger$ (Child's Demographics and Birth Characteristics): adjusted for gestational age, birthweight adjusted for gestational age, mode of delivery, child's sex, child's race/ethnicity

\# (Mother's Demographics): adjusted for maternal pre-regnancy BMI, maternal race/ethnicity, maternal level of education, maternal atopy, antibiotic exposure during pregnancy, smoking during pregnancy, $6 \mathrm{~m}$ or $1 \mathrm{yr}$ \#\# Model 3 (All Demographics and Birth Characteristics): adjusted for all demographics and characteristics in models 1 and 2 except maternal race/ethnicity. This the reported value in manuscript. 
Table 4. Association Between Cord Blood Serum Protein Concentration and Pulmonary Function Tests

\begin{tabular}{|c|c|c|c|c|c|}
\hline & \multicolumn{2}{|c|}{ Mid-Childhood } & \multicolumn{2}{|c|}{ Early-Teen } \\
\hline & & $\begin{array}{l}\text { FEV1/FVCx100 } \\
\beta(95 \% \mathrm{Cl})\end{array}$ & $\begin{array}{c}\text { BDR } \\
\beta(95 \% \mathrm{Cl})\end{array}$ & $\begin{array}{c}\text { FEV1/FVCx100 } \\
\beta(95 \% \mathrm{Cl})\end{array}$ & $\begin{array}{c}\text { BDR } \\
\beta(95 \% \mathrm{Cl})\end{array}$ \\
\hline \multicolumn{6}{|l|}{$\begin{array}{l}\text { PGLYRP-1 } \\
\text { Z-Score* }^{*}\end{array}$} \\
\hline & Univariate & $1.38(0.15,2.61)$ & $0.10(-1.83,2.03)$ & $1.45(0.49,2.42)$ & $-0.68(-1.54,0.17)$ \\
\hline & Model $1^{\dagger}$ & $1.12(-0.18,2.41)$ & $0.53(-1.44,2.51)$ & $1.05(0.11,1.98)$ & $-0.49(-1.40,0.41)$ \\
\hline & Model $2^{\#}$ & $1.38(0.08,2.69)$ & $0.61(-1.40,2.63)$ & $1.53(0.54,2.53)$ & $-0.58(-1.49,0.34)$ \\
\hline & Model $3^{\# \#}$ & $1.19(-0.19,2.56)$ & $1.00(-1.04,3.04)$ & $1.15(0.20,2.10)$ & $-0.35(-1.29,0.59)$ \\
\hline \multicolumn{6}{|l|}{$\begin{array}{l}\text { slL6Ra } \\
\text { Z-Score* }\end{array}$} \\
\hline & Univariate & $0.95(-0.31,2.20)$ & $-0.38(-2.45,1.69)$ & $0.11(-0.86,1.09)$ & $0.65(-0.24,1.54)$ \\
\hline & Model $1^{\dagger}$ & $0.96(-0.30,2.21)$ & $-0.37(-2.41,1.67)$ & $0.02(-0.87,0.92)$ & $0.71(-0.19,1.61)$ \\
\hline & Model $2^{\#}$ & $0.88(-0.40,2.16)$ & $-0.62(-2.62,1.39)$ & $-0.02(-1.00,0.97)$ & $0.75(-0.17,1.66)$ \\
\hline & Model $3^{\# \#}$ & $0.92(-0.36,2.20)$ & $-0.11(-0.96,0.70)$ & $-0.05(-0.94,0.85)$ & $0.79(-0.12,1.69)$ \\
\hline
\end{tabular}

* Serum protein concentrations were log10 transformed and converted into an internal Z-score

$\dagger$ (Child's Demographics and Birth Characteristics): adjusted for gestational age, birthweight adjusted for gestational age, mode of delivery, child's sex, child's race/ethnicity

\# (Mother's Demographics): adjusted for maternal pre-regnancy BMI, maternal race/ethnicity, maternal level of education, maternal atopy, antibiotic exposure during pregnancy, smoking during pregnancy, $6 \mathrm{~m}$ or $1 \mathrm{yr}$ \#\# Model 3 (All Demographics and Birth Characteristics): adjusted for all demographics and characteristics in models 1 and 2 except maternal race/ethnicity. This the reported value in manuscript. 
medRxiv preprint doi: https://doi.org/10.1101/2020.06.17.20127407; this version posted June 22, 2020. The copyright holder for this preprint (which was not certified by peer review) is the author/funder, who has granted medRxiv a license to display the preprint in perpetuity.

All rights reserved. No reuse allowed without permission.

\section{Supplemental Information}

\section{Perinatal Granulopoiesis and Risk of Pediatric Asthma}

Turturice, BA et al. 


\section{Supplemental Data Description}

Title: Supplemental Data 1

Description: Meta-Analysis of CBMC Gene Expression Associated with Newborn Sex

Title: Supplemental Data 2

Description: Meta-Analysis of CBMC Gene Expression Associated with Gestational Age

Title: Supplemental Data 3

Description: Meta-Analysis of CBMC Gene Expression Associated with Birthweight

Title: Supplemental Data 4

Description: Meta-Analysis of CBMC Gene Expression Associated with Maternal Pre-pregnancy BMI

Title: Supplemental Data 5

Description: Demographics of UIH Cohort

Title: Supplemental Data 6

Description: Result of mRNAseq UIH Cohort Modeling Gene Expression as a Function of Number of Risk Factors

Title: Supplemental Data 7

Description: Demographics of Project Viva Subset Dichotomized by Asthma Outcomes 
medRxiv preprint doi: https://doi.org/10.1101/2020.06.17.20127407; this version posted June 22, 2020. The copyright holder for this preprint (which was not certified by peer review) is the author/funder, who has granted medRxiv a license to display the preprint in perpetuity.

All rights reserved. No reuse allowed without permission.

\section{List of Supplemental Figures}

Figure S1. Association between Differentially Methylated Genes and Gene Expression Changes with Gestational Age.

Figure S2. Replication Score Enriches for Genes Associated with Multiple Risk Factors.

Figure S3. Protein-Protein Interaction Network of Candidate Genes.

Figure S4. Association between PGLYRP-1 and s/L6Ra in UIH and Project Viva Cohorts.

Figure S5. Cord Blood Serum Proteins in Relationship to Outcomes.

Figure S6. Relative importance of predictors for pediatric asthma and FEV1/FVC.

Figure S7. Subset analysis for all covariates used in regression models. 
medRxiv preprint doi: https://doi.org/10.1101/2020.06.17.20127407; this version posted June 22, 2020. The copyright holder for this preprint (which was not certified by peer review) is the author/funder, who has granted medRxiv a license to display the preprint in perpetuity.

All rights reserved. No reuse allowed without permission.

\section{Supplemental References}

33. Bohlin J, Håberg SE, Magnus P, Reese SE, Gjessing HK, Magnus MC, et al. Prediction of gestational age based on genome-wide differentially methylated regions. Genome Biol. 201610 07,;17(1):207.

67. Szklarczyk D, Gable AL, Lyon D, Junge A, Wyder S, Huerta-Cepas J, et al. STRING v11: protein-protein association networks with increased coverage, supporting functional discovery in genome-wide experimental datasets. Nucleic Acids Res. 2019 01 08,;47(D1):D607-13. 


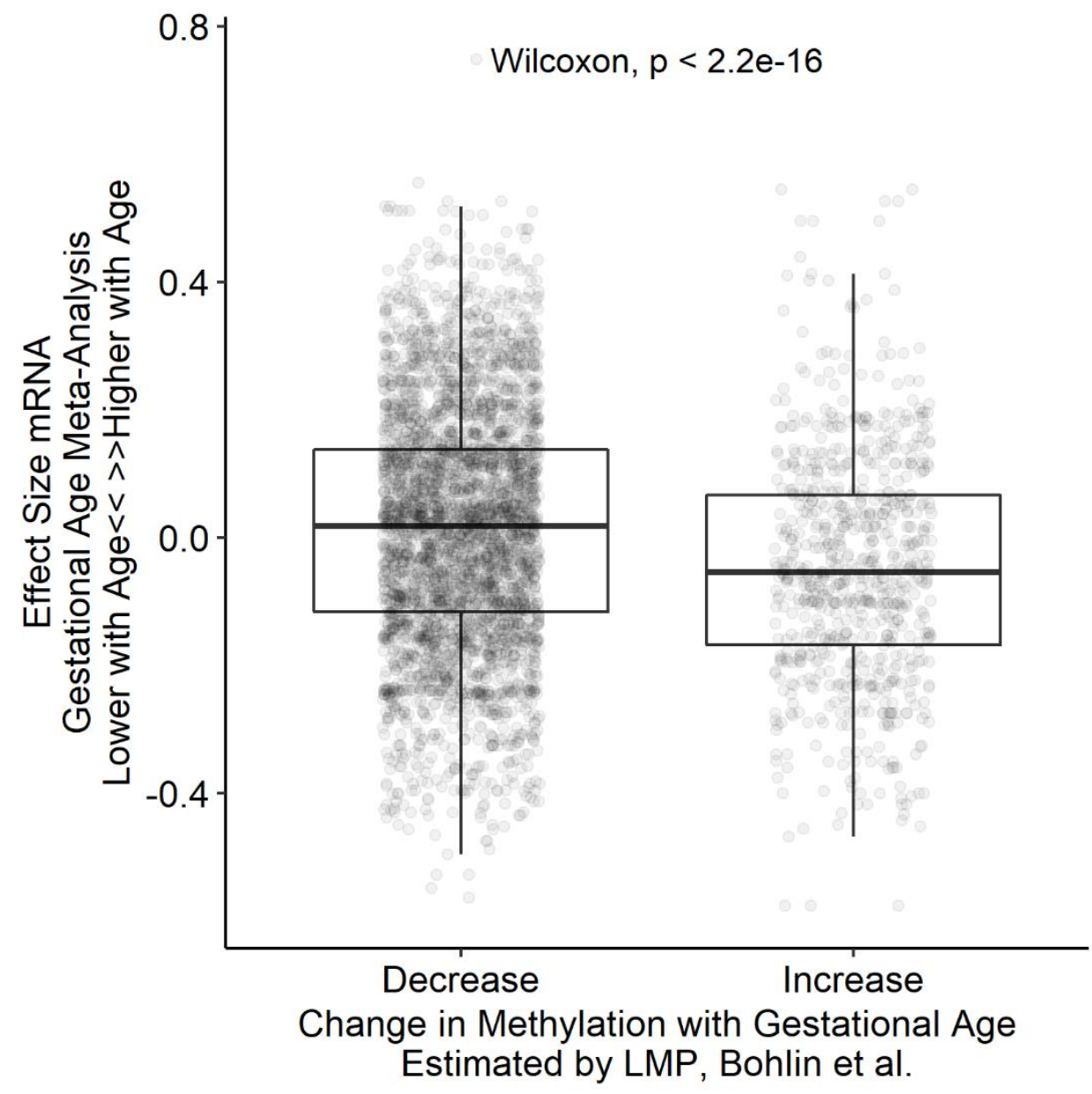

Figure S1. Association between Differentially Methylated Genes and Gene Expression Changes with Gestational Age. Comparison of effect size associated with gestational age for genes that were reported as differentially methylated by Bolin et al. (33). Gene with increased methylation associated with gestational age demonstrate reduced expression with increasing gestational age. 


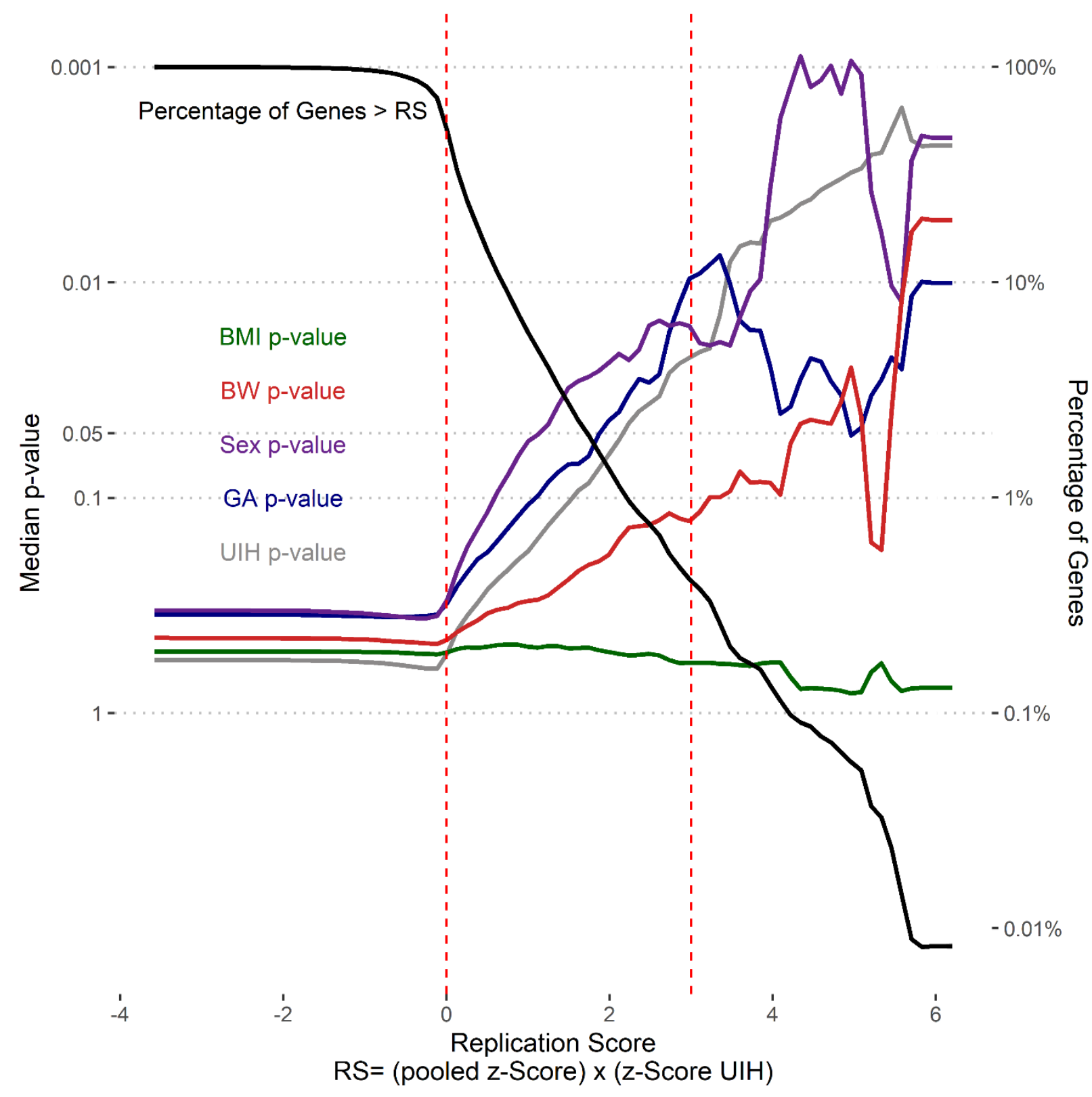

Figure S2. Replication Score Enriches for Genes Associated with Multiple Risk Factors. Splines (colored according to analysis) of median $p$-values (left y-axis) for genes with replication scores greater than corresponding cut-off (x-axis). Percentage of genes with replication score greater than corresponding cut-off. Vertical dashed lines two cutoffs: RS $>0$ and RS $>3$. 


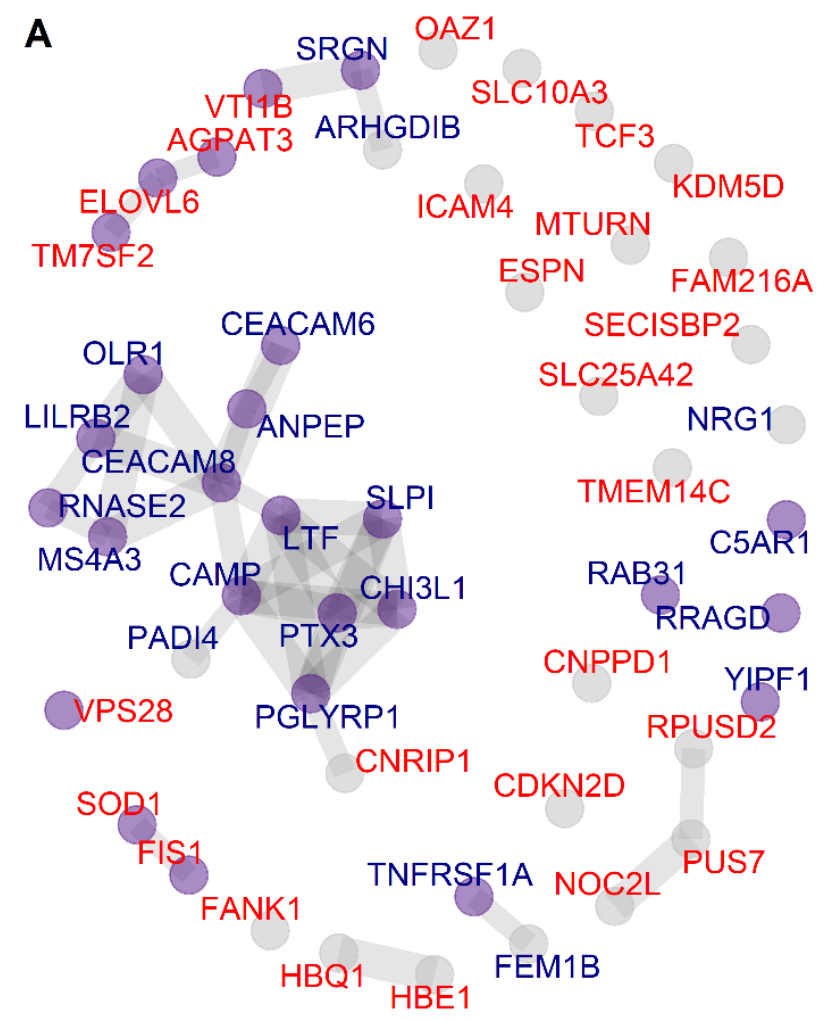

B

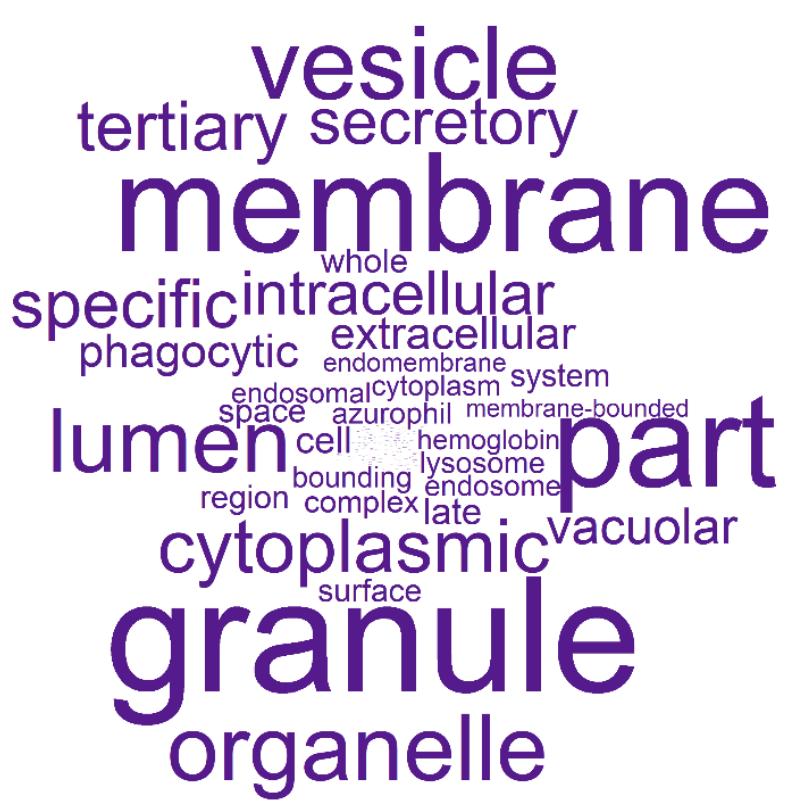

Figure S3. Protein-Protein Interaction Network of Candidate Genes. (A) Protein-Protein interaction network of candidate genes inferred from STRING (67). Nodes are labeled by risk association: low (blue) and high (red) risk candidate genes. Nodes are colored (purple) if they are associated with GO cellular component term enrichment. (B) Word clouds of GO terms significantly enriched in candidate genes. 
medRxiv preprint doi: https://doi.org/10.1101/2020.06.17.20127407; this version posted June 22, 2020. The copyright holder for this preprint (which was not certified by peer review) is the author/funder, who has granted medRxiv a license to display the preprint in perpetuity. All rights reserved. No reuse allowed without permission.

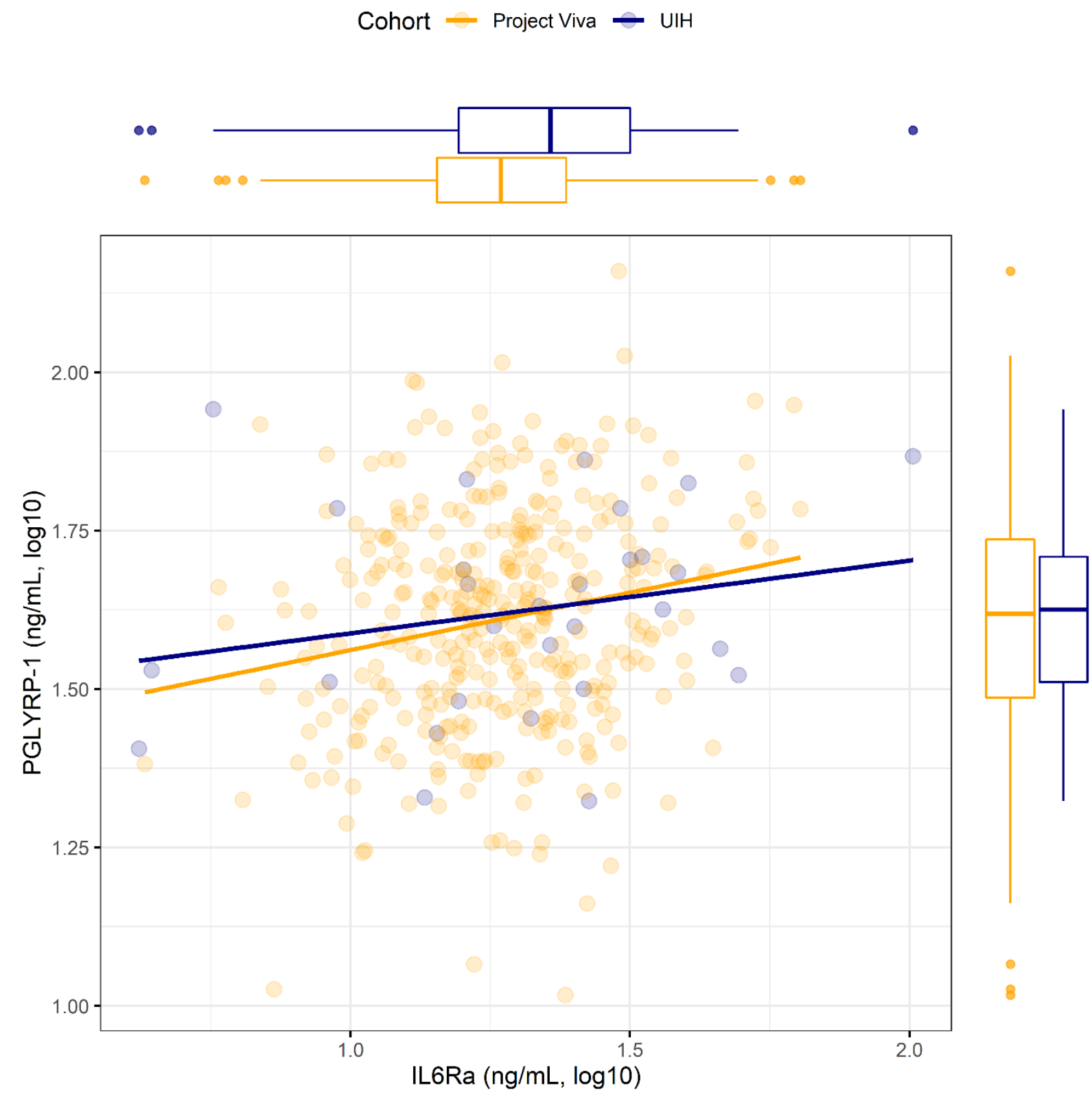

Figure S4. Association between PGL YRP-1 and sIL6Ra in UIH and Project Viva Cohorts. Scatter plot displaying association between PGLYRP-1 and sIL6Ra in UIH (blue) and Project Viva (yellow) cohorts. Univariate regression lines are shown for both cohorts. Distributions for PGLYRP-1 and sIL6Ra are shown in the margins for each cohort. 

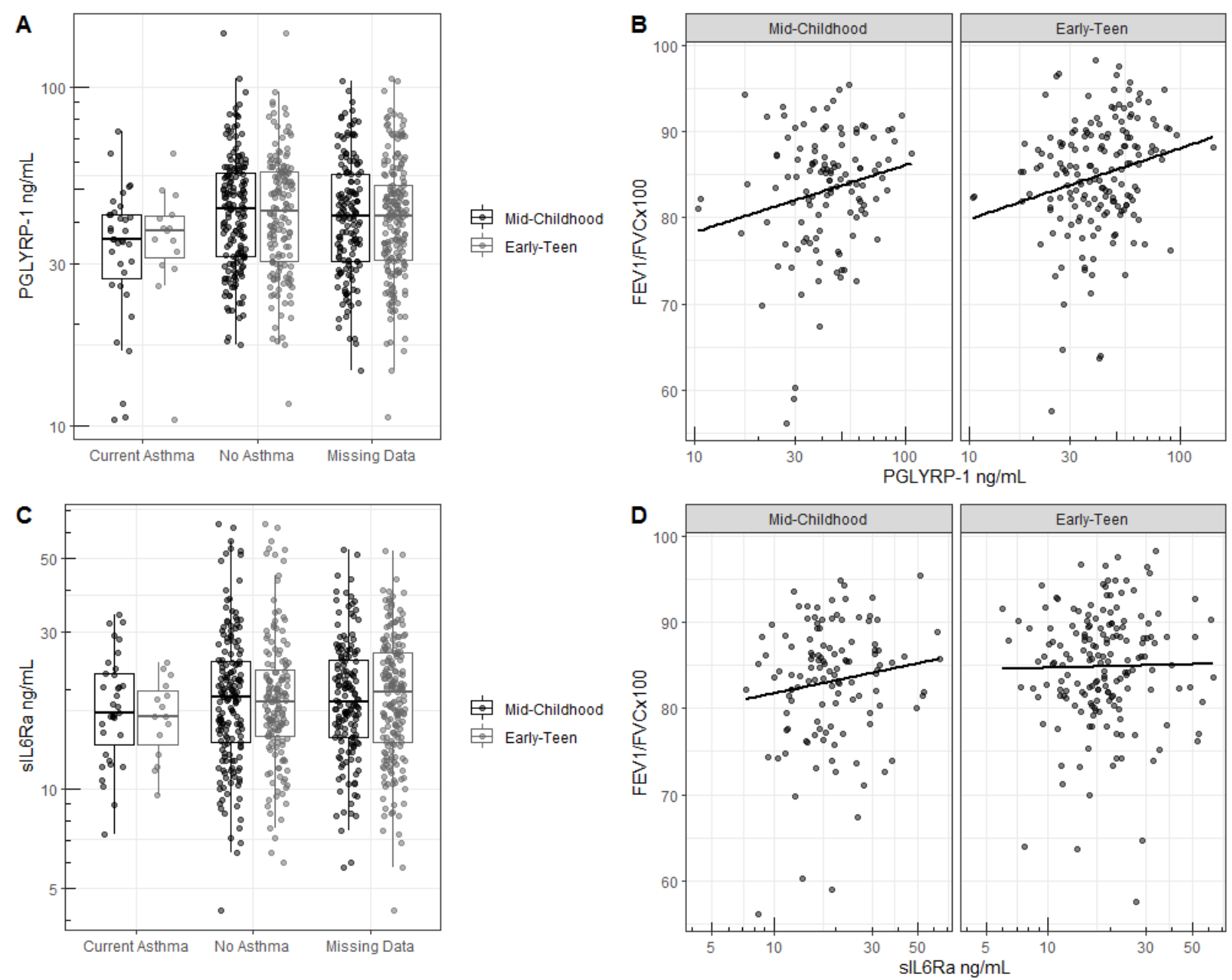

Figure S5. Cord Blood Serum Proteins in Relationship to Outcomes. (A) PGLYRP-1 concentration in umbilical cord blood serum in relationship to current asthma determined by questionnaire response and (B) FEV1/FVCx100 at mid-childhood and early-teenage follow-ups. (C) sIL6Ra concentration in umbilical cord blood serum in relationship to current asthma determined by questionnaire response and (D) FEV1/FVCx100 at mid-childhood and earlyteenage follow-ups. 
medRxiv preprint doi: https://doi.org/10.1101/2020.06.17.20127407; this version posted June 22, 2020. The copyright holder for this preprint (which was not certified by peer review) is the author/funder, who has granted medRxiv a license to display the preprint in perpetuity.

All rights reserved. No reuse allowed without permission.

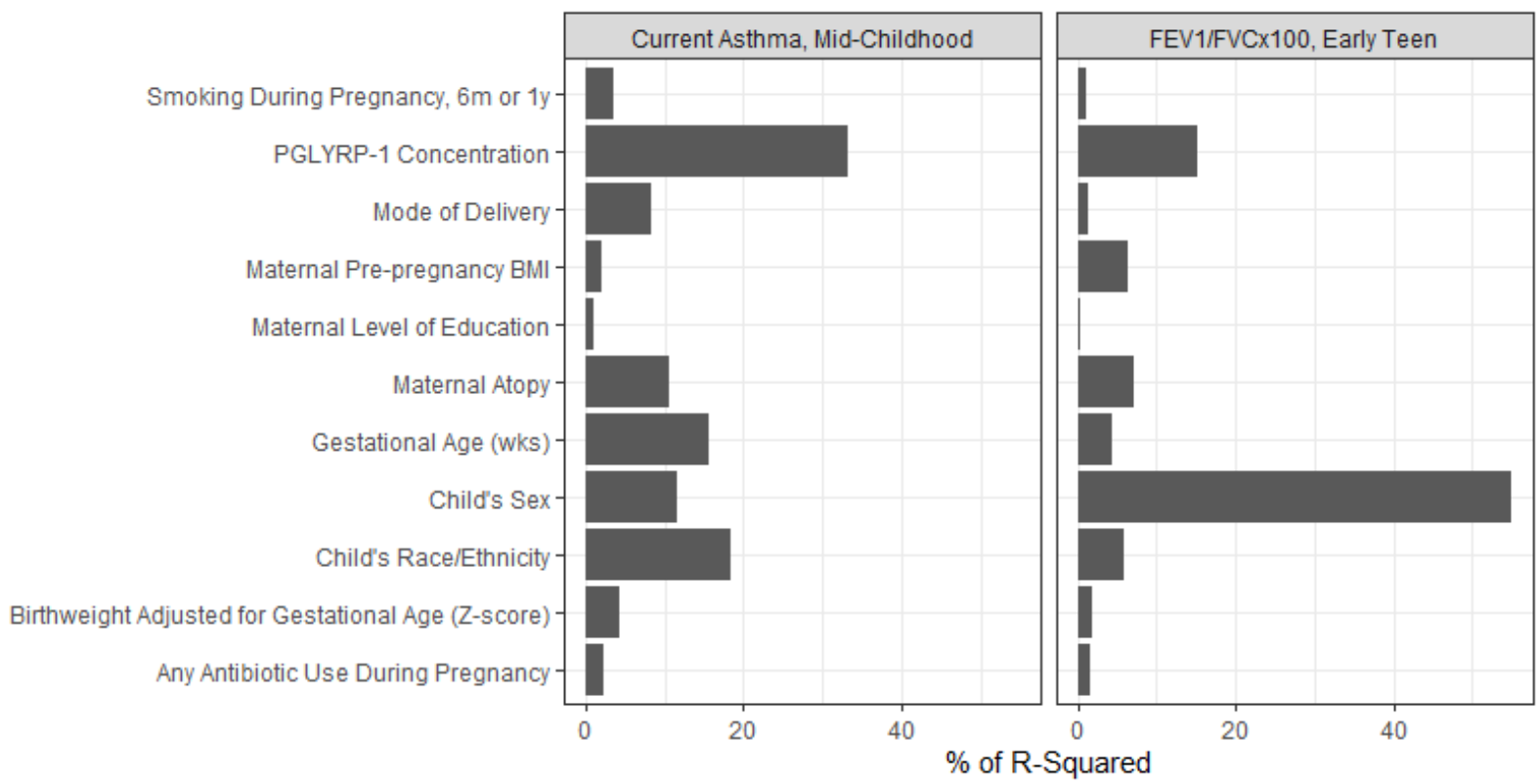

Figure S6. Relative importance of predictors for pediatric asthma and FEV1/FVC. Relative importance, displayed as percent of variance explained, for variables used in regressions (Table 3, Model 3) for current asthma at mid-childhood and FEV1/FVC in early teen years. Variance estimated for logistic regression as Mcfadden's Pseudo- $R^{2}$. 

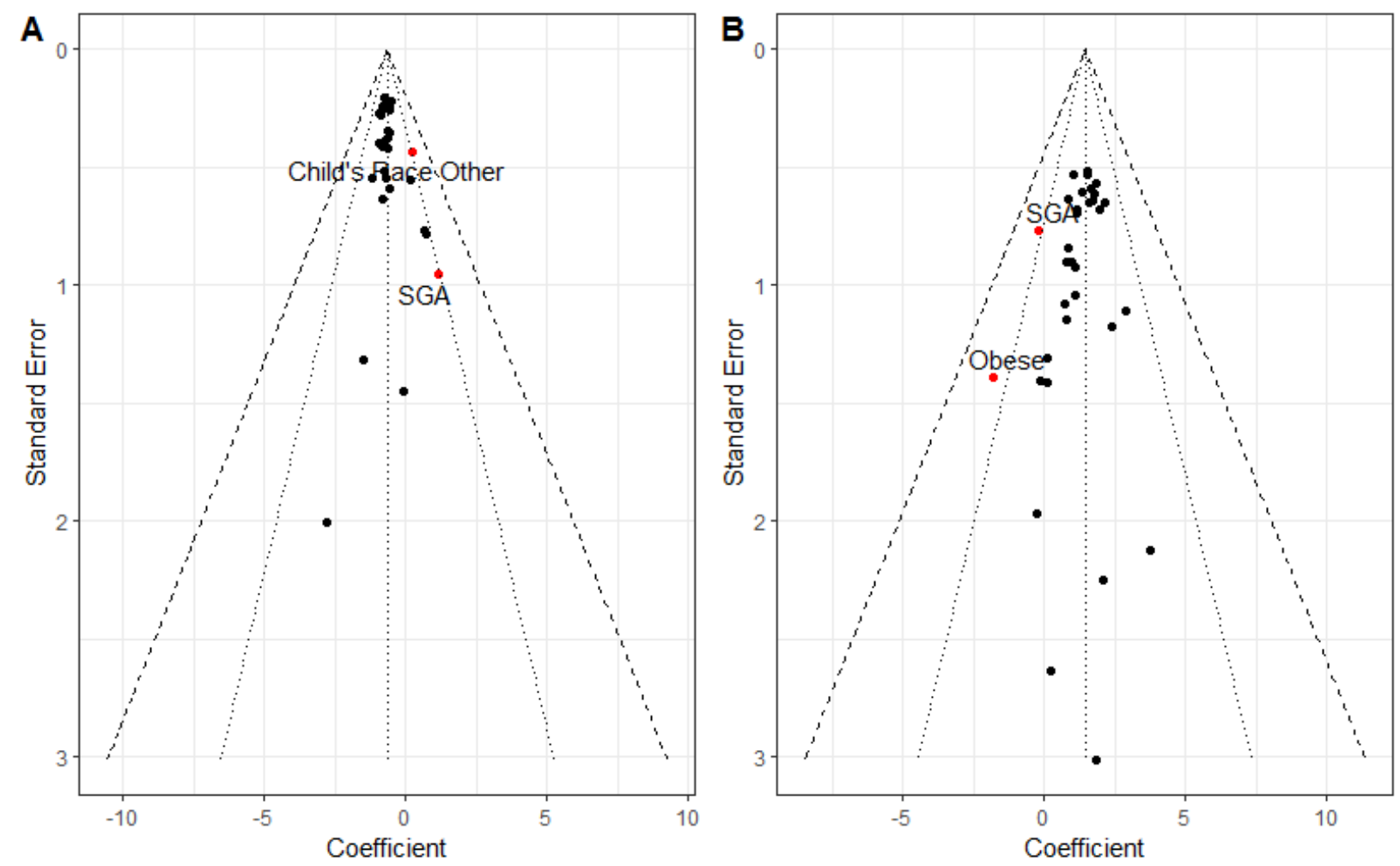

Figure S7. Subset analysis for all covariates used in regression models. Funnel plot demonstrating relationship effect size estimates and measurement error for subset analyses for (A) current mid-childhood asthma and (B) FEV1/FVCx100 in early teen years. $95 \% \mathrm{Cl}$ (botted lines) and $99 \% \mathrm{Cl}$ (dashed lines) displayed. 
medRxiv preprint doi: https://doi.org/10.1101/2020.06.17.20127407; this version posted June 22, 2020. The copyright holder for this preprint (which was not certified by peer review) is the author/funder, who has granted medRxiv a license to display the preprint in perpetuity.

All rights reserved. No reuse allowed without permission. 